\title{
Deletion of the transcription factor Prox-1 specifically in the renal distal convoluted tubule causes hypomagnesemia via reduced expression of TRPM6 and NCC
}

\author{
Christina Schnoz ${ }^{1} \cdot$ Sandra Moser ${ }^{1} \cdot$ Denise V. Kratschmar $^{2} \cdot$ Alex Odermatt $^{2,3} \cdot$ Dominique Loffing-Cueni $^{1}$. \\ Johannes Loffing ${ }^{1,3}$ (D)
}

Received: 14 August 2020 / Revised: 25 October 2020 / Accepted: 5 November 2020 / Published online: 16 November 2020

(C) The Author(s) 2020

\begin{abstract}
The renal distal convoluted tubule (DCT) is critical for the fine-tuning of urinary ion excretion and the control of blood pressure. Ion transport along the DCT is tightly controlled by posttranscriptional mechanisms including a complex interplay of kinases, phosphatases, and ubiquitin ligases. Previous work identified the transcription factor Prox-1 as a gene significantly enriched in the DCT of adult mice. To test if Prox-1 contributes to the transcriptional regulation of DCT function and structure, we developed a novel mouse model $\left(\mathrm{NCC}^{\text {cre }}:\right.$ Prox $\left.-1^{\text {flox/flox }}\right)$ for an inducible deletion of Prox-1 specifically in the DCT. The deletion of Prox-1 had no obvious impact on DCT structure and growth independent whether the deletion was achieved in newborn or adult mice. Furthermore, DCT-specific Prox-1 deficiency did not alter DCT-proliferation in response to loop diuretic treatment. Likewise, the DCT-specific deletion of Prox-1 did not cause other gross phenotypic abnormalities. Body weight, urinary volume, $\mathrm{Na}^{+}$and $\mathrm{K}^{+}$excretion as well as plasma $\mathrm{Na}^{+}, \mathrm{K}^{+}$, and aldosterone levels were similar in Prox $-1_{\mathrm{DCT}}{ }_{\mathrm{KO}}$ and Prox $-1_{\mathrm{DCT}}{ }_{\mathrm{Ctrl}}$ mice. However, Prox- $1_{\mathrm{DCT}}{ }^{\mathrm{KO}}$ mice exhibited a significant hypomagnesemia with a profound downregulation of the DCT-specific apical $\mathrm{Mg}^{2+}$ channel TRPM6 and the $\mathrm{NaCl}$ cotransporter (NCC) at both mRNA and protein levels. The expression of other proteins involved in distal tubule $\mathrm{Mg}^{2+}$ and $\mathrm{Na}^{+}$handling was not affected. Thus, Prox-1 is a DCT-enriched transcription factor that does not control DCT growth but contributes to the molecular control of DCT-dependent $\mathrm{Mg}^{2+}$ homeostasis in the adult kidney.
\end{abstract}

Keywords Kidney $\cdot$ Renal distal convoluted tubule (DCT) $\cdot$ DCT adaptation $\cdot$ Transcription factor Prox- $1 \cdot \mathrm{NaCl}$ cotransporter (NCC) · Transient receptor potential cation channel subfamily M member 6 (TRPM6)

\section{Introduction}

The renal distal convoluted tubule (DCT) is crucial for the control of ion homeostasis and the regulation of arterial blood pressure [28]. Although only 5-10\% of the sodium $\left(\mathrm{Na}^{+}\right)$filtered at the glomerulus is reabsorbed in the DCT, the $\mathrm{Na}^{+}$transport activity of the DCT is the highest of all nephron portions, which is reflected by a very high mitochondrial density in DCT cells.

Johannes Loffing

johannes.loffing@anatomy.uzh.ch

1 Institute of Anatomy, University of Zurich, Winterthurerstrasse 190, CH-8057 Zurich, Switzerland

2 Division of Molecular and Systems Toxicology, Department of Pharmaceutical Sciences, University of Basel, Basel, Switzerland

3 National Centre of Competence in Research "Kidney.CH", University of Zurich, 8057 Zurich, Switzerland
The $\mathrm{Na}^{+}$transport in the DCT is driven by the basolateral $\mathrm{Na}^{+}-$ $\mathrm{K}^{+}$-ATPase and critically depends on the activity of the thiazidesensitive $\mathrm{NaCl}$ cotransporter (NCC) in the apical plasma membrane of DCT cells $[28,30]$. The DCT is also important for the control of renal magnesium $\left(\mathrm{Mg}^{2+}\right)$ excretion as the DCT is the sole site for active transcellular $\mathrm{Mg}^{2+}$ reabsorption along the nephron. The $\mathrm{Mg}^{2+}$ reabsorption in the DCT is mediated by the apical transient receptor potential cation channel subfamily M member 6 (TRPM6) [46] and modulated by the $\gamma$-subunit of the $\mathrm{Na}^{+}-\mathrm{K}^{+}$-ATPase encoded by the FXYD2 gene [2, 27].

Genetic diseases affecting the DCT evidence the significance of the DCT for the control of ion homeostasis and blood pressure [28]. In Gitelman syndrome, loss-of-function mutations in NCC lead to an autosomal recessive renal tubulopathy characterized by renal salt-wasting with low blood pressure, hypokalemic alkalosis, hypocalciuria, and hypomagnesemia [40]. Conversely, an inappropriate increase in NCC activity due to mutations in NCC-regulating with no lysine $(K)$ kinases 
(WNK1 and 4) or ubiquitin ligase complexes (KLHL3, CUL3) causes salt-sensitive familial hyperkalemic hypertension (FHHt) with metabolic acidosis and hypercalciuria, also known as Gordon syndrome or pseudohypoaldosteronism type II (PHA II) [12, 28, 41]. Likewise, mutations in TRPM6 [36, 48] and FXYD2 [29] cause renal tubulopathies with magnesium wasting and hypomagnesemia [45].

The last couple of years brought tremendous insights into the molecular signaling mechanism that control the function of the DCT. A complex network of various kinases, phosphatases, and ubiquitin ligases was shown to regulate the DCT function. For example, the STE20-related proline-alanine-rich kinase (SPAK) and the oxidative-stress-responsive 1 kinase (OSR1) are known to directly phosphorylate and thereby activate NCC [13]. The activity of SPAK and OSR 1 itself is controlled by the upstream kinases WNK1 and WNK4 [51] that again are regulated via the ubiquitin ligase complex proteins kelch-like 3 (KLHL3) and cullin 3 (CUL3) [13, 41]. The abundance of NCC is also directly regulated by ubiquitinylation via Nedd4 2 and the upstream kinase Sgk1 [34]. Phosphatases such as protein phosphatase 1 (PP1), 3 (PP3 or calcineurin), and 4 (PP4) can counteract the activity of the kinases and inactivate NCC [11]. Similar to NCC, the activity of TRPM6 is also controlled by several kinases. For example, the stimulatory effect of the epidermal growth factor (EGF) on TRPM6 is thought to be mediated by both Src-Family Kinases and mitogen-activated kinases (MAPK) and their downstream mediator PI3-kinase [43]. Likewise, AKT/PKB and Cdk5 were implicated in the insulin-dependent regulation of TRPM6 [45].

Despite this significant progress, we still lack a comprehensive understanding of the regulatory mechanisms that govern the DCT. In particular, we lack significant information about the transcriptional control mechanism. Genetic studies linked the hepatocyte nuclear factor 1 beta (HNF1b) and its cofactor PCBD1 to the regulation of TRPM6 [1,20], but the role of other DCT-expressed transcription factors is less clear. Previously, we identified the transcription factor Prospero Homeobox 1 (Prox-1) as a gene that is about 100 times more abundant in the DCT than in in the sum of all other renal tubules of adult mouse kidney [33]. Together with NCC and TRPM6, Prox-1 belongs to the 20 gene products most enriched in the mouse DCT suggesting a specific role in this tubule segment. Also in the adult rat kidney, Prox-1 appears to be predominately if not exclusively expressed in the DCT as indicated by a comprehensive database on RNAseq data from isolated renal tubules [23].

Prox-1 is a transcription factor containing an evolutionary conserved homeobox-prospero domain that binds DNA and RNA and allows transcriptional regulation of other genes. It plays an essential role during developmental processes such as cell proliferation, cell fate determination, and progenitor cell differentiation in numerous mammalian organs (lymphatic system, CNS, eye, heart, liver, and pancreas) $[8,10,32,49]$. Moreover, alterations in Prox-1 expression have been associated with several human malignancies including hematological diseases; brain tumors; and carcinomas of colon, pancreas, and liver, and the biliary system $[10,32]$. In the kidney, Prox-1 is highly expressed in distal tubules of the developing mouse kidney where it is involved in differentiation and outgrowth of the medullary part of the loop of Henle [17]. As in the adult kidney, Prox-1 is enriched in the DCT $[23,33]$, we hypothesized that Prox-1 may contribute to the transcriptional control of DCT function. As a constitutive Prox-1 knockout is embryonically lethal [50], we developed a novel mouse model that allowed an inducible, DCT-specific deletion of Prox-1 in the adult kidney.

\section{Material and methods}

\section{Animals}

Mice with "floxed" alleles for Prox-1 were a kind gift from Dr. G. Oliver (Chicago, USA). In this conditional knockout mouse model, exons 2 and 3 of the Prox- 1 gene are flanked by loxP sites. Cre recombinase mediated deletion of these two exons removes the homeodomain and Prox domain and renders Prox1 transcriptionally inactive [14]. To target specifically the DCT, a mouse model with a tamoxifen-inducible cre activity in the DCT was custom-made by the company Ozgene (Bentley, Australia). In these mice, the cre-ERT2 was introduced into the three prime untranslated region (3'-UTR) of the Slc12a3/ NCC gene, where it is expressed using the same internal ribosomal entry site (IRES) as the Slc12a3/NCC gene (Fig. 1A). TdTomato-red reporter mice [26] were obtained from The Jackson Laboratories Repository. All experiments involving living animals were conducted in accordance with Swiss laws and approved by the veterinary administration of the Canton of Zurich (Kantonales Veterinäramt), Switzerland.

\section{Tamoxifen administration}

Tamoxifen induction was performed in male mice 1-2 weeks after weaning (i.e., at the age of 35-45 days). Tamoxifen (Sigma-Aldrich, T5648) was dissolved in EtOH: sunflower oil (1:10). A dose of $2 \mathrm{mg}$ per day was administered to the mice via gastric gavage on 5 subsequent days, 6 weeks prior to the experiments. The same dosage and procedure were applied to breastfeeding mother mice to induce cre expression in the newborn offspring.

\section{Plasma and urine ion measurement}

Blood collection Blood was sampled by puncture of the inferior vena cava of isoflurane-anesthetized animals. Whole blood was centrifuged for $10 \mathrm{~min}$ at $3000 \mathrm{~g}$ and plasma was removed subsequently. 
Fig. 1 Characterization of NCCcre-ERT2 mice. A Schematic representation of insertion of the tamoxifen-inducible creERT2 in the untranslated region (UTR) of the last exon of the Slc12a3/NCC gene. B Immunostaining for NCC, cre, and calbindin D28K (CB28) on consecutive cryosections from NCC-cre-ERT2 mice. Tamoxifen induces strong nuclear localization of the cre recombinase in NCC-positive DCT1 (1) and in DCT2 (2) with strong NCC and CB28-immunostaining. C Overviews on kidneys from NCC-cre-ERT2/tomato-flox mice (upper panel) show a strong tomato-related fluorescence in a kidney of tamoxifen-induced but not in the kidney of an uninduced mouse. High-power magnification (lower panel) demonstrate that the tomato-related fluorescence is strictly limited to the DCT (D) and is not found in the preceding NKCC2-positive TAL (T) and the downstream localized AQP2-positive CNT (CN). The segment transitions are indicated by double-headed arrows. Two pairs of consecutive cryosections. $\mathbf{D}$ and $\mathbf{E}$ Immunoblots and densitometry reveal that the creERT2 transgene does not interfere with NCC abundance and phosphorylation. Data are mean $\pm \mathrm{SEM}, n=$ 3 a

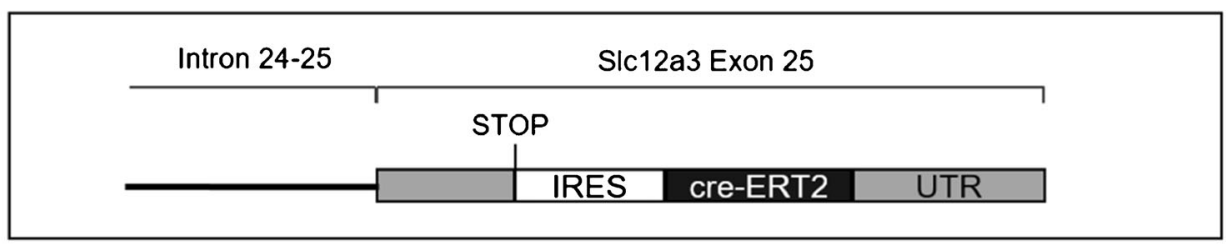

b

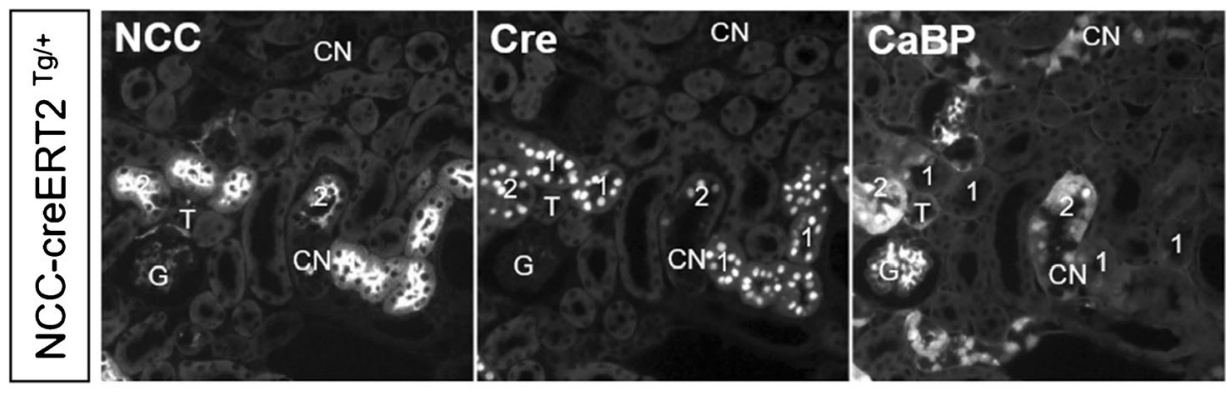

C
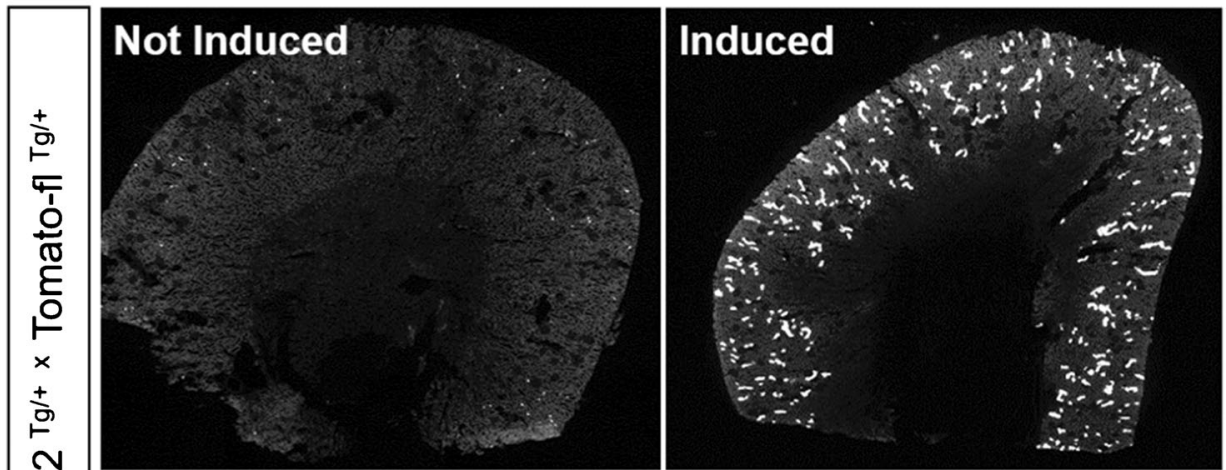
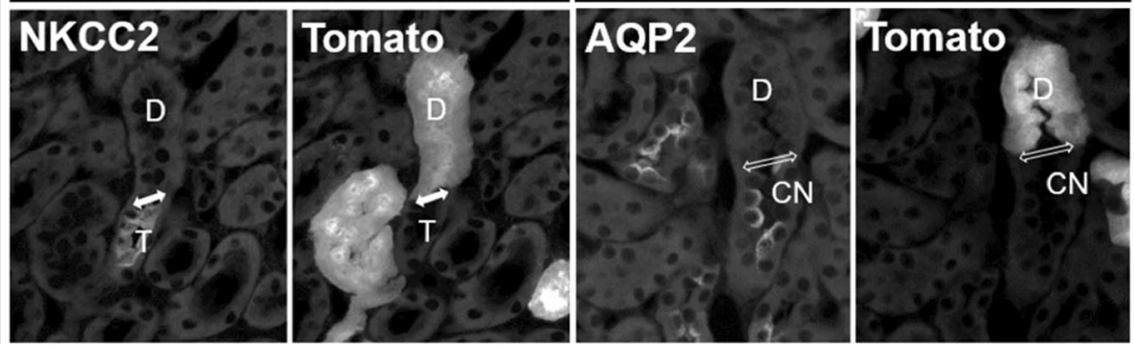

d

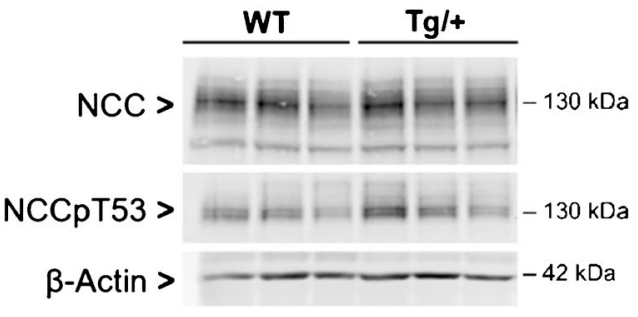

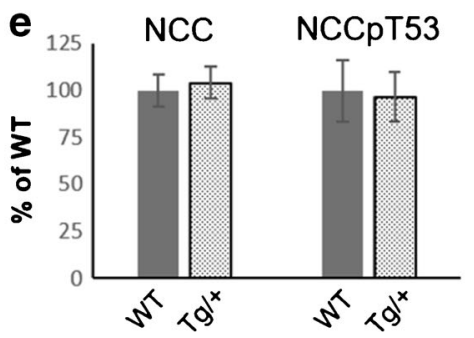

Plasma $\mathrm{Na}^{+}, \mathrm{K}^{+}$, and $\mathrm{Ca}^{2+}$ measurement Blood ions $\left(\mathrm{Na}^{+}, \mathrm{K}^{+}\right.$, $\mathrm{Ca}^{2+}$ ) were measured with the ABL80Flex Blood Gas Analyzer (Radiometer, Copenhagen, Denmark).

Plasma and urine $\mathrm{Mg}^{2+}$ and $\mathrm{PO}_{4}{ }^{3-}$ measurement Plasma and urine $\mathrm{Mg}^{2+}$ and $\mathrm{PO}_{4}{ }^{3-}$ measurements were performed by the Zurich Integrative Rodent Physiology (University of Zurich) using photometric methods (UniCel DxC 800, Beckman Coulter, Brea, CA, USA).

Urine $\mathrm{Na}^{+}, \mathrm{K}^{+}$, and $\mathrm{Ca}^{2+}$ measurement Urine was collected for $24 \mathrm{~h}$ from mice kept individually in metabolic cages (Tecniplast S.p.A., Buguggiate, Italy). Urinary electrolytes $\left(\mathrm{Na}^{+}, \mathrm{K}^{+}, \mathrm{Ca}^{2+}\right)$ were measured by flame photometry 
(EFOX 5053, Eppendorf, Hamburg, Germany). Urine creatinine was assessed by the Jaffe method.

\section{Aldosterone, 11-deoxycorticosterone, and corticosterone measurement}

Aldosterone, 11-deoxycorticosterone, and corticosterone were determined by ultra-performance liquid chromatography-MS/ MS (UPLC-MS/MS) as described previously with minor adaptations [42] using an Agilent 1290 Infinity II UPLC coupled to an Agilent 6495 triple quadrupole mass spectrometer. Data acquisition and quantitative analysis was performed by MassHunter (Version B.10.0. Build 10.0.27, Agilent Technologies).

\section{Kidney harvesting and tissue processing}

Immunofluorescence The kidneys of isoflurane-anesthetized adult mice were fixed by retrograde abdominal aortic perfusion of 3\% paraformaldehyde (PFA) followed by rinsing with $0.1 \mathrm{M}$ phosphate buffer $(\mathrm{pH} 7.4,300 \mathrm{mOsm})$ and paraffin embedding. The kidneys of 10-day-old isofluraneanesthetized pups were immersion fixed with paraformaldehyde (PFA) $3 \%$ for $12-16 \mathrm{~h}$, then incubated in $0.1 \mathrm{M}$ phosphate buffer ( $\mathrm{pH} 7.4,300 \mathrm{mOsm})$ for $4 \mathrm{~h}$ and finally embedded in paraffin.

Western blot and quantitative reverse transcription PCR For western blot analysis and RNA extraction, perfusion was performed with PBS ( $\mathrm{pH}$ 7.4) via the left ventricle of the heart; kidneys were removed and frozen in liquid nitrogen.

\section{Immunohistochemistry}

Tissue blocks were sectioned at $4 \mu \mathrm{m}$ on a standard rotary microtome (Microm HM355S, Thermo Fisher Scientific, Waltham, MA, USA). The Pathisto AS-2 automatic slide stainer (Pathisto GmbH, Garbsen, Germany) was utilized for deparaffination using Histo-clear and for tissue rehydration using serial ethanol washes. For epitope retrieval, slides were heated in $10 \mathrm{mM}$ citrate buffer $(\mathrm{pH} 6.0)$ in a microwave $\left(98^{\circ} \mathrm{C}, 10 \mathrm{~min}\right.$ ). After blocking with $10 \%$ normal goat serum (10 $\mathrm{min}$ ), the sections were incubated overnight in a humidified chamber at $4{ }^{\circ} \mathrm{C}$ with the primary antibodies. The dilutions of the previously generated und described primary antibodies are shown in supplementary table 1 . Secondary antibodies (Cy3-conjugated goat-anti-rabbit IgG, catalogue code 111-165-144, dilution 1/1000 and FITC-conjugated goatanti-mouse IgG, catalogue code 115-095-068, dilution $1 / 100$, both from Jackson Immuno Research Laboratories, West Grove, PA) were applied for $2 \mathrm{~h}$ at room temperature and sections were finally mounted using DABKO-glycergel and coverslips. Images were acquired at a Leica DM6000 B fluorescence microscope on Leica DFC350 FX fluorescence monochrome digital camera (Leica Microsystems, 35578 Wetzlar, Germany).

\section{Western blot analysis}

Sample preparation Kidneys were homogenized in ice-cold lysis buffer (Mannitol $200 \mathrm{mM}$, HEPES $80 \mathrm{mM}$, KOH $41 \mathrm{mM}$ ) containing protease inhibitor (Complete Ultra, Roche) and phosphatase inhibitor (PhosSTOP, Roche) using MagNA Lyser Green Beads (Roche) and Precellys 24 tissue homogenizer (Bertin Instruments), $2 \times 20 \mathrm{~s}$ (2000 $\mathrm{g}$ ). The homogenized samples were centrifuged for $10 \min (1700 \mathrm{~g})$ and the protein-containing supernatant was removed and stored at $-80{ }^{\circ} \mathrm{C}$.

SDS-PAGE and Western blot Equal amounts of protein $(25 \mu \mathrm{g})$ from kidney samples were denatured in Laemmli Buffer (SDS, $\beta$-mercaptoethanol, bromophenol blue, glycerol and $0.5 \mathrm{M}$ Tris-HCl buffer, $\mathrm{pH}$ 6.8), separated by SDS-page, and electrophoretically transferred onto nitrocellulose membranes. The membranes were blocked with Odyssey Blocking solution (LI-COR Biosciences) $(10 \mathrm{~min})$ and then incubated at $4{ }^{\circ} \mathrm{C}$ for $16 \mathrm{~h}$ with the primary antibodies (see table 1 of supplementary data) diluted in Odyssey Blocking buffer: PBS (1:5). After repeated washes with PBS, blots were incubated at room temperature for $2 \mathrm{~h}$ with secondary antibodies (goat-anti-rabbit IRDye 800, product number 926-32211 and goat-anti-mouse IRDye 680, product number 926-32220, $1: 20^{\prime} 000$, both from LI-COR Biosciences), in Casein Blocking solution: $\mathrm{H} 2 \mathrm{O}$ (1:10). Immunoreactive bands were visualized and quantified with the Odyssey IR imaging system and software (LI-COR Biosciences) and normalized for either $\beta$-actin or the total protein signal obtained by REVERT Total Protein Stain (LI-COR Biosciences).

\section{RNA isolation and quantitative PCR}

RNA isolation and CDNA generation from total kidney tissue Total RNA from kidney tissue was isolated using Promega kit (SV Total RNA Isolation System, catalog number Z3100), according to the manufacturer's protocol. cDNA was generated using Promega kit (GoScript ${ }^{\mathrm{TM}}$ Reverse Transcription System, catalog number A5000) as per the manufacturer protocol. For whole kidney tissue, cDNA was further diluted to 1:5 in $\mathrm{H}_{2} \mathrm{O}$.

RNA isolation and CDNA generation from isolated DCTs Manually microdissected tubules were frozen in RNA lysis buffer containing $\beta$-mercaptoethanol, and RNA was isolated using Absolutely RNA Nanoprep kit (Agilent Technologies, catalog number 400753), following manufacturer's protocol. cDNA was generated using Sensifast cDNA Synthesis kit 
(Bioline, catalog number BIO65053), and undiluted cDNA was used for RT-qPCR.

Real-time quantitative PCR Expression levels of the genes of interest were quantified by real-time quantitative PCR using Light Cycler II 480 (Roche). Real-time PCR reactions were prepared using $5.0 \mu \mathrm{l}$ of LightCycler 480 SYBR Green I Master (Roche), $3.75 \mu \mathrm{l}$ of RNase free water, $0.25 \mu \mathrm{l}$ of each primer $(100 \mu \mathrm{M}$ ), and $0.75 \mu \mathrm{l}$ of cDNA (final reaction volume of $10 \mu \mathrm{l})$. Gene-specific primer sequences are listed in table 2 of supplementary data. Specificity of the primers was first tested in a standard PCR with subsequent separation of PCR products in a $2 \%$ agarose gel. Relative mRNA gene expression was measured after normalization to GAPDH gene expression (total kidney) and ribosomal RNA gene expression (isolated DCTs).

\section{Manual microdissection of distal convoluted tubules}

Manual microdissection of distal convoluted tubules was conducted according to a previously published protocol [47]. After perfusion of anesthetized mice with MEM media (GibcoBRL, Ref number 11058021) via left ventricle, the kidney was sagittally cut into two halves and the medulla was excised. Cortex was sliced into $1-\mathrm{mm}$ thin sections that were then incubated in a digestion solution containing $4 \mathrm{ml}$ MEM, $5 \mathrm{mM}$ glycine, $6 \mathrm{mg} / \mathrm{ml}$ trypsin inhibitor (Trypsin inhibitor from Glycine max, Sigma-Aldrich, T9128), and $250 \mu \mathrm{g} / \mathrm{ml}$ collagenase (Collagenase from Clostridium histolyticum, Sigma-Aldrich, C9891), pH 7.4 at $37{ }^{\circ} \mathrm{C}$ for 25 min without shaking. The digested cortex sections were subsequently washed with ice-cold HEPES solution $(\mathrm{NaCl}$ $125 \mathrm{mM}, \mathrm{KCl} 3 \mathrm{mM}, \mathrm{MgSO}_{4} 1.2 \mathrm{mM}, \mathrm{CaCl}_{2} 1 \mathrm{mM}$, $\mathrm{KH}_{2} \mathrm{PO}_{4} 2 \mathrm{mM}$, glucose $5 \mathrm{mM}$, HEPES $32.2 \mathrm{mM}$ ), and the renal DCTs were manually microdissected under a stereomicroscope based on their distinct morphological characteristic.

\section{Implantation of mini-osmotic pump}

Loading mini-osmotic pumps Bumetanide (Sigma-Aldrich, B3023) (dosage of $40 \mathrm{mg} / \mathrm{kg}$ body weight/day) and bromodeoxyuridine (Sigma-Aldrich, B5002) (dosage $40 \mathrm{mg} / \mathrm{kg}$ body weight/day) were dissolved in $\mathrm{H}_{2} \mathrm{O}$ : PEG300 (1:5) with incubation on a thermo shaker on $36^{\circ} \mathrm{C}$, $1000 \mathrm{rpm}$, overnight. Mini-osmotic pumps from Alzet ${ }^{\circledR}$ (model 2001, DURECT Corporation, Cupertino, CA, USA) with a filling volume of $200 \mu \mathrm{l}$ and a pump delivery rate of $1 \mu \mathrm{l} / \mathrm{h}$ were used. One day prior to pump implantation, the mini-osmotic pumps were loaded with appropriate volume $(200 \mu \mathrm{l})$ of the solution as directed by manufacturer using the provided needle. The loaded mini-osmotic pumps were primed in sterile $\mathrm{NaCl} 0.9 \%$ at $37^{\circ} \mathrm{C}$ overnight according to the supplier's instruction.

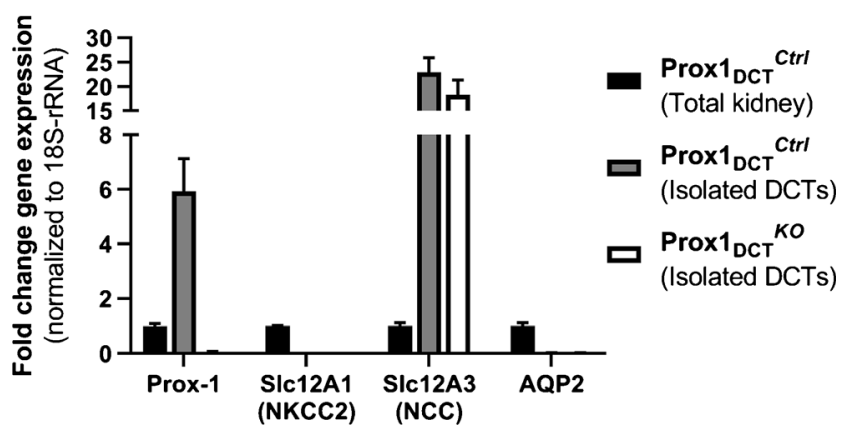

Fig. 2 Prox-1, Slc12A1/NKCC2, Slc12A3/NCC, and AQP2 mRNA expression in Prox- $1_{\mathrm{DCT}}{ }^{C r l}$ versus Prox- $1_{\mathrm{DCT}}{ }^{\text {KO }}$ isolated DCTs and in total kidney tissue. Prox-1: Prox-1 gene expression is significantly increased in isolated DCTs (Prox-1 $1_{\mathrm{DCT}}{ }_{\mathrm{Ctrl}}$ ) compared to whole kidney tissue $\left(\right.$ Prox- $\left.1_{\mathrm{DCT}}{ }^{\mathrm{Ctrl}}\right)(p=0.0035)$. Confirmation of a Prox-1 deletion with almost none Prox-1 mRNA expression in isolated DCTs from Prox$1_{\mathrm{DCT}}{ }^{K O}$ mice compared to isolated DCTs from Prox- $1_{\mathrm{DCT}}{ }^{\text {Ctrl }}$ mice $(p=$ 0.000006). Slc12A1/NKCC2, AQP2: No contamination of isolated DCTs (Prox- $1_{\mathrm{DCT}}{ }^{C t r l}$ and Prox- $1_{\mathrm{DCT}}{ }^{K O}$ ) with other nephron segments, confirmed by absent Slc12A1/NKCC2 and AQP2 gene expression in DCT samples. Slc12A3/NCC: 20-30-fold higher Slc12A3/NCC expression in isolated DCTs compared to total kidney tissue. Kidneys and renal tubules were isolated 1 week after start of tamoxifen induction. Data are mean \pm SEM, expressed as fold difference compared to the gene expression in the total kidney group, $n=5$

Surgical implantation in mice Mice were anesthetized with isoflurane and buprenorphine $0.01 \mathrm{mg} / \mathrm{kg}$ body weight (Temgesic ${ }^{\circledR}, 0.3 \mathrm{mg} / \mathrm{ml}$, Indivior Schweiz AG, 3015880). For implantation of the pump, mice were placed in a prone position. A skin incision $(1-2 \mathrm{~cm})$ was made across the neck and a subcutaneous pocket was created using blunt forceps. After inserting the pump into the subcutaneous pouch, the skin wound was closed with two surgical clips.

\section{Semi-thin sections}

For semi-thin sectioning, kidneys were fixed by vascular perfusion with 3\% PFA as described above and postfixed in the same fixative to which $1 \%$ glutaraldehyde was added. The tissue was embedded in epoxy resin (EPON) and semi-thin sections of $0.8 \mu \mathrm{m}$ were cut with an ultramicrotome (Leica UltraCut $\mathrm{E}$ ultramicrotome). For staining, slides were incubated at $60{ }^{\circ} \mathrm{C}$ for $2 \mathrm{~min}$ in $0.5 \%$ toluidine blue (Merck, 11593) and $0.5 \%$ sodium tetraborate decahydrate (Sigma-Aldrich, S9640), diluted in water, followed by coverslip mounting with Entellan new (Merck 1079610100).

\section{Morphometric measurements}

The fractional cortical tubular volume of DCT segments was assessed according to a previously described protocol [38]. Paraffin sections of kidneys were immunostained with an antibody against NCC (table 1 of supplementary material) and images were taken from each kidney section with the $\times 10$ objective of the fluorescence microscope. DCTs were 
identified according to the antibody-staining pattern and the fractional cortical tubular volumes for DCTs were determined using a planimetric point-counting method performed with a computerized image analysis system (Stereo Investigator, MBF Bioscience, Williston USA).

\section{Statistical analysis}

Unpaired two-tailed $t$ test and 2-way ANOVA were used to compare the groups (GraphPad Prism, Version 8.0.2). Data are given as means $\pm \mathrm{SEM}$. Values were considered as significantly different when $p<0.05$.

\section{Results}

\section{Development and characterization of a new mouse model for inducible DCT-specific gene targeting}

For a DCT-specific deletion of Prox-1, we first developed and characterized a novel mouse model with a tamoxifen-inducible cre activity in the DCT (see "Material and methods"). Upon tamoxifen administration, these mice show a strong nuclear localization of the cre recombinase specifically in the DCT (Fig. 1B), comprising both DCT1 and DCT2 as identified by their characteristic staining pattern for NCC and calbindin D28K [24]. Using a tdTomato-red reporter mouse line [26], we found that cre-mediated recombination is negligible without tamoxifen induction, but increases drastically in cortical tubules when tamoxifen is administered for 5 days. Higher magnifications showed that the cre-mediated recombination starts precisely at the transition from TAL to DCT and ends at the transition from DCT to CNT (Fig. 1C). Immunoblotting confirmed that the insertion of the cre-ERT2 in the $3^{\prime}$ UTR of NCC does not interfere with NCC expression and phosphorylation (Fig. 1D, E). Thus, this new NCC-cre-ERT2 mouse model allows a timed gene targeting restricted to the DCT. Unlike to a recently published mouse model with constitutive cre expression under the control of the NCC promoter [44], the new mouse model does not show evidence for cre-mediated recombination in nonDCT cells. Similar observations were made by the group of Jim McCormick who just reported a similar NCC-cre-ERT2 mouse model generated by a similar gene-modification strategy as we employed [5].

\section{Prox-1 is enriched in adult mouse DCT}

Prox-1 mRNA expression was determined in manually dissected DCTs from both Prox- $1_{\mathrm{DCT}}{ }^{\mathrm{Ctrl}}$ and Prox$1_{\mathrm{DCT}}{ }^{\mathrm{KO}}$ mice as well as from total kidney homogenates from Prox- $1_{\mathrm{DCT}}{ }^{\mathrm{Ctrl}}$ mice. Comparing Prox-1 mRNA abundance in isolated DCT segments (ctrl) and total kidney tissue (ctrl), Prox-1 mRNA transcript levels showed a 5-6-fold enrichment in the DCT (Fig. 2). In the Prox $-1_{\mathrm{DCT}}{ }^{\mathrm{KO}}$ mice, hardly any Prox- 1 expression was detectable in the isolated DCTs, confirming the efficacy of the DCT-specific Prox-1 deletion in our mouse model (Fig. 2). Isolated DCTs were not contaminated with other tubular segments, confirmed by absent Slc12A1/NKCC2 and AQP2 gene expression.

\section{No gross pathological characteristics in Prox-1 ${ }_{\mathrm{DCT}}{ }^{\mathrm{KO}}$ mice}

Breeding of NCC-cre-ERT2 with floxed Prox-1 animals resulted in a normal Mendelian inheritance pattern. Creinduction and excision of the Prox-1 gene in DCT cells were induced upon tamoxifen administration either immediately after birth or at the age of weaning. Independent from the time point of induction, all mice with DCT-specific Prox-1 deletion (Prox- $1_{\mathrm{DCT}}{ }^{\mathrm{KO}}$ ) did

Table 1 Metabolic parameters, plasma and urine electrolyte concentrations and plasma aldosterone, 11-deoxycorticosterone, and corticosterone in Prox- $1_{\mathrm{DCT}}{ }^{\mathrm{KO}}$ mice

\begin{tabular}{|c|c|c|}
\hline & Prox $1_{\mathrm{DCT}}{ }^{\mathrm{Ctrl}}$ & $\operatorname{Prox} 1_{\mathrm{DCT}}{ }^{K O}$ \\
\hline Age (days) & $90 \pm 1$ & $100 \pm 3$ \\
\hline Body weight (g) & $31.3 \pm 0.9$ & $31.6 \pm 1.0$ \\
\hline Food intake (g/day) & $7.3 \pm 0.6$ & $5.9 \pm 0.3$ \\
\hline Water intake (ml/day) & $2.6 \pm 0.6$ & $3.3 \pm 0.8$ \\
\hline Urine volume (ml/day) & $1.2 \pm 0.3$ & $1.1 \pm 0.3$ \\
\hline Plasma $\mathrm{Na}^{+}(\mathrm{mmol} / \mathrm{l})$ & $149.4 \pm 0.6$ & $150.9 \pm 1.3$ \\
\hline Plasma $\mathrm{K}^{+}(\mathrm{mmol} / \mathrm{l})$ & $4.0 \pm 0.1$ & $4.1 \pm 0.2$ \\
\hline Plasma $\mathrm{Ca}^{2+-}(\mathrm{mmol} / \mathrm{l})$ & $1.26 \pm 0.03$ & $1.25 \pm 0.03$ \\
\hline Plasma $\mathrm{Mg}^{2+}(\mathrm{mmol} / \mathrm{l})$ & $0.85 \pm 0.03 *$ & $0.76 \pm 0.03 *$ \\
\hline Plasma $\mathrm{HCO}^{-}(\mathrm{mmol} / \mathrm{l})$ & $19.3 \pm 0.5$ & $20.0 \pm 0.5$ \\
\hline Plasma PO4 ${ }^{3-}(\mathrm{mmol} / \mathrm{l})$ & $1.61 \pm 0.12$ & $1.83 \pm 0.15$ \\
\hline Plasma aldosterone (nM) & $0.32 \pm 0.04$ & $0.37 \pm 0.09$ \\
\hline Plasma 11-Deoxycorticosterone (nM) & $1.38 \pm 0.36$ & $0.98 \pm 0.37$ \\
\hline Plasma corticosterone (nM) & $107.7 \pm 20.8$ & $92.9 \pm 19.0$ \\
\hline Urine $\mathrm{Na}^{+} /$urine creat. $(\mathrm{mmol} / \mathrm{mmol})$ & $40.8 \pm 6.0$ & $41.4 \pm 4.0$ \\
\hline Urine $\mathrm{K}^{+} /$urine creat. (mmol/mmol) & $179.4 \pm 17.2$ & $147.6 \pm 11.3$ \\
\hline Urine $\mathrm{Ca}^{2+} /$ urine creat. (mmol/mmol) & $0.84 \pm 0.14$ & $0.60 \pm 0.12$ \\
\hline Urine $\mathrm{Mg}^{2+} /$ urine creat. $(\mathrm{mmol} / \mathrm{mmol})$ & $3.70 \pm 1.13$ & $1.83 \pm 0.77$ \\
\hline
\end{tabular}

Prox- $1_{\mathrm{DCT}}{ }^{K O}$ mice exhibit a significant hypomagnesemia $(p=0.036)$ compared to the Prox- $1_{\mathrm{DCT}}{ }_{\text {Ctrl }}$ group. For other metabolic parameters, plasma electrolytes, plasma aldosterone, 11-deoxycorticosterone, corticosterone, and urinary ion excretion, no difference was detected between the genotypes. Values are means \pm SEM. $n=11$ (plasma electrolytes), $n=13$ (plasma $\mathrm{Mg}^{2+}$ ), $n=7$ (aldosterone, 11-deoxycorticosterone, and corticosterone), $n=5$ (body weight, food and water intake, urine excretion, urine electrolytes) 

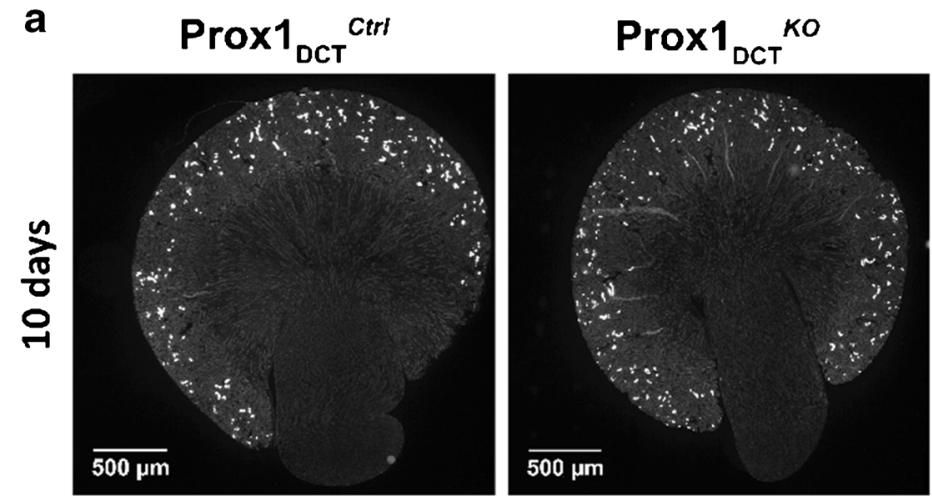

b
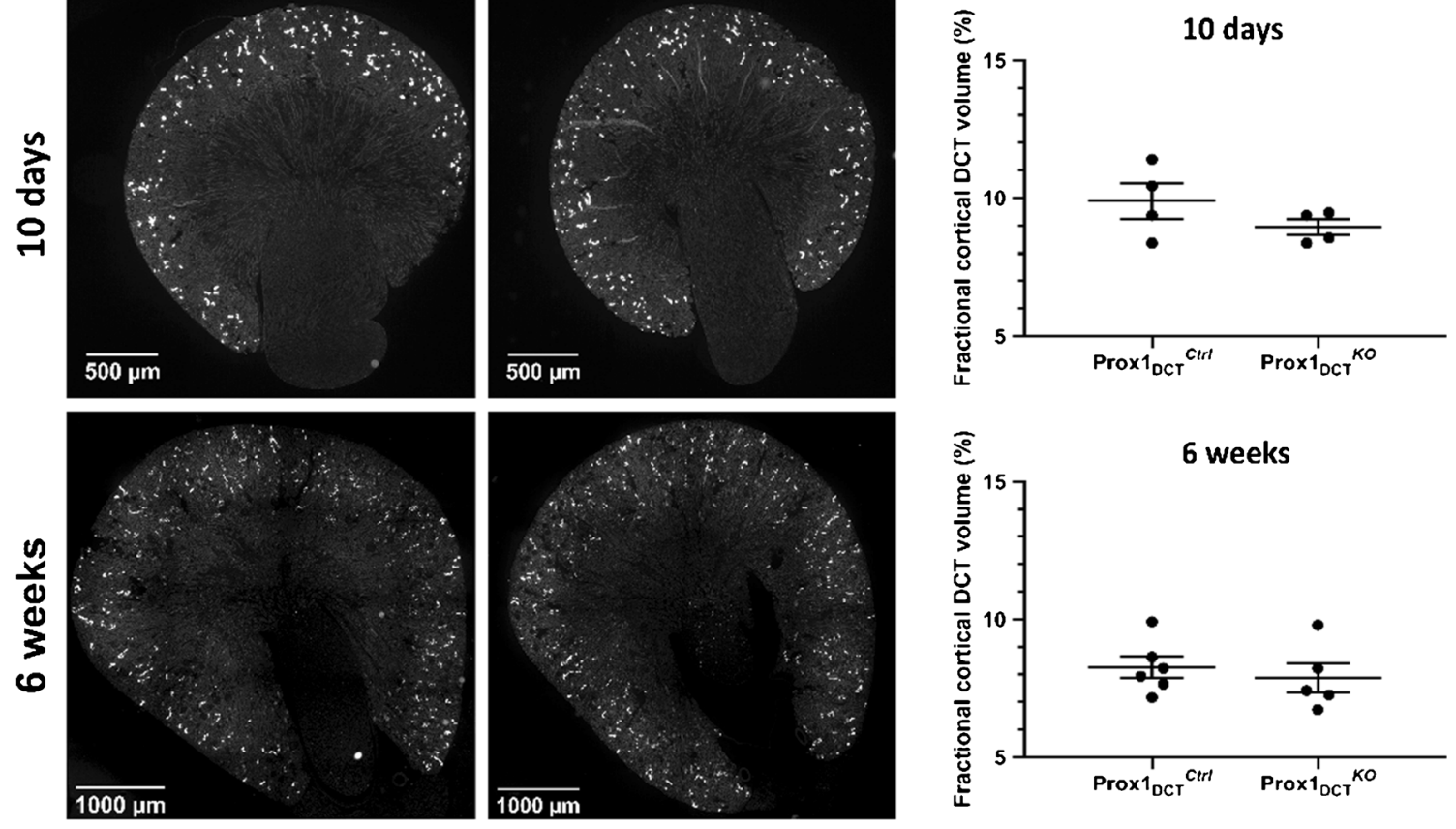

C
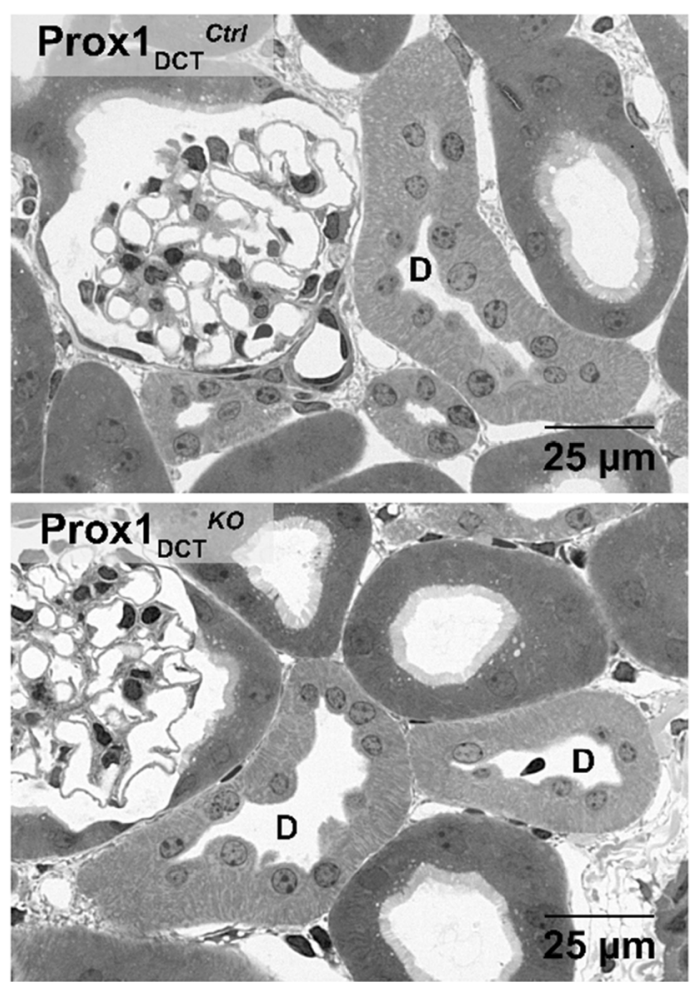

Fig. 3 DCT morphology and fractional cortical volume of DCT in Prox$1_{\mathrm{DCT}}{ }^{\mathrm{Ctrl}}$ versus Prox- $1_{\mathrm{DCT}}{ }^{\mathrm{KO}}$ mice at age 10 days and 6 weeks. A NCC protein expression (immunostaining on paraffin sections) in kidneys of 10-day-old pups (upper panel) and 6-week-old (lower panel) Prox$1_{\mathrm{DCT}}{ }^{\mathrm{Ctrl}}$ versus Prox- $1_{\mathrm{DCT}}{ }^{\mathrm{KO}}$ mice. Cre recombination and deletion of Prox-1 in the DCT was induced immediately after birth. B No difference in the fractional cortical volume $(\%)$ of whole DCT in Prox- $1_{\mathrm{DCT}}{ }_{\mathrm{Ctrl}}$

versus Prox- $1_{\mathrm{DCT}}{ }^{\mathrm{KO}}$ mice was observed upon deletion of Prox-1, neither in pups nor in 6-week-old mice. DCTs were identified due to NCC immunostaining. Values are means \pm SEM. $n=4$ (10 days, ctrl + ko), $n=6$ (6 weeks, ctrl), $n=5$ (6 weeks, ko). C Distal convoluted tubules (D) in the renal cortex of Prox- $1_{\mathrm{DCT}}{ }^{\mathrm{Ctrl}}$ and Prox- $1_{\mathrm{DCT}}{ }^{\mathrm{KO}}$ mice reveal a normal DCT morphology (adult kidneys) in both genotypes, epon semi-thin sections 
Fig. 4 DCT cell proliferation rate in Prox- $1_{\mathrm{DCT}}{ }^{\mathrm{Ctrl}}$ versus Prox$1_{\mathrm{DCT}}{ }^{\mathrm{KO}}$ mice in response to a 3 day treatment with bumetanide. A Paraffin sections of Prox- $1_{\text {DCT }}$ Ctrl mice kidneys (upper panel) and Prox- $1_{\mathrm{DCT}}{ }_{\mathrm{KO}}$ mice kidneys (lower panel) after a 3-day treatment with bumetanide and BrdU (right) or BrdU only (left). A doubleimmunostaining for NCC (red) and BrdU (green) allowed for the identification of DCT segments and proliferating DCT cells. B A significant increase in DCT cell proliferation rate was achieved in Prox- $1_{\mathrm{DCT}}{ }^{\mathrm{Crr}}(p=0.0001)$ and Prox- $1_{\mathrm{DCT}}{ }^{\mathrm{KO}}(p=0.0007)$ by the administration of bumetanide and BrdU compared to the situation where mice received BrdU only. However, no difference in the proliferation rate between the different genotypes was observed.

Data are mean \pm SEM, $n=6$

(BrdU only), $n=5$ (Bumetanide + BrdU, ctrl), $n=4$ (Bumetanide + BrdU, ko)

\section{a}

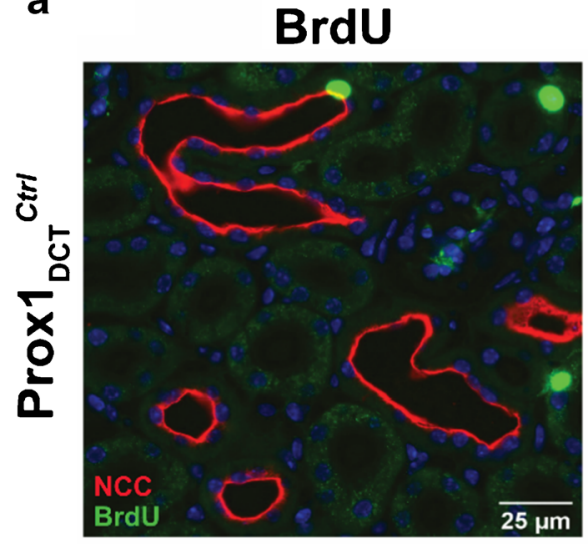

Bumetanide + BrdU
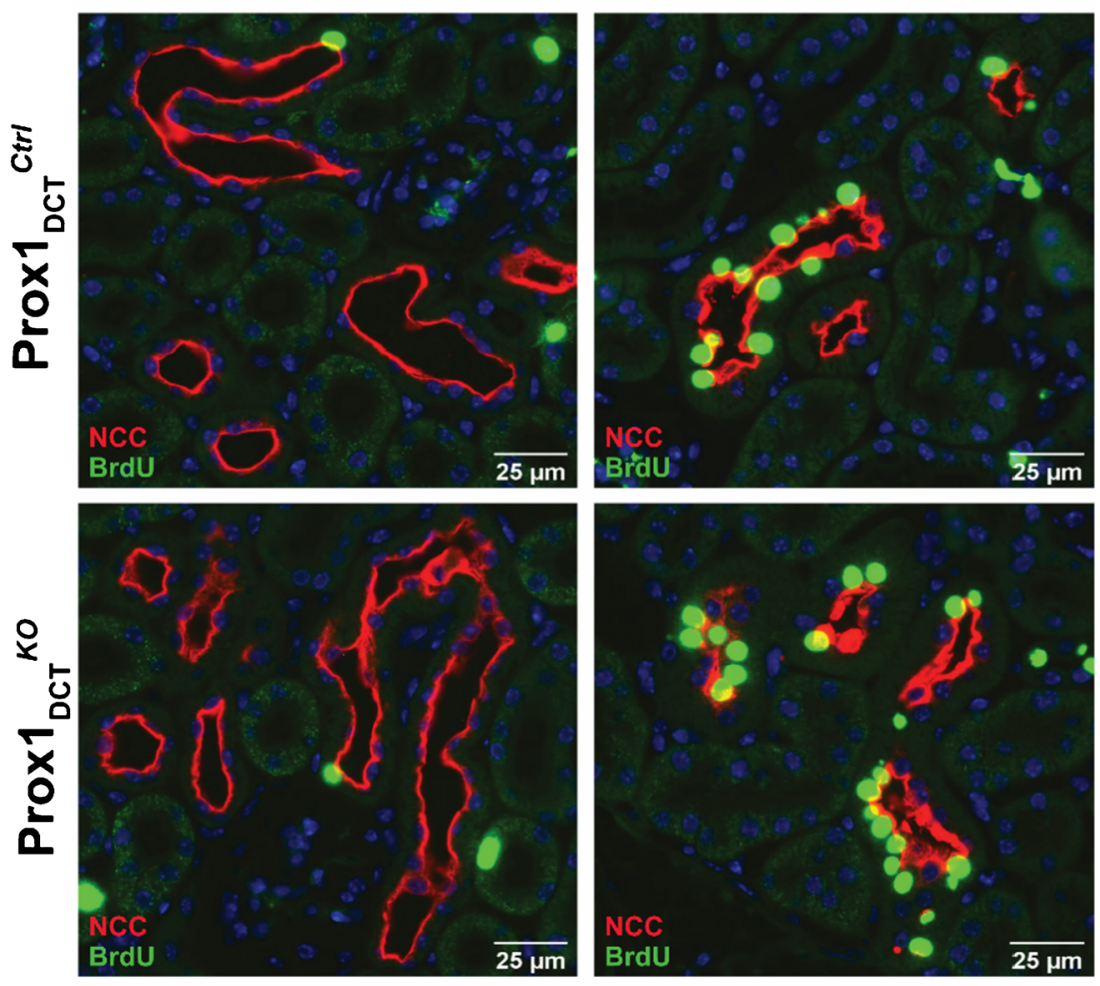

b

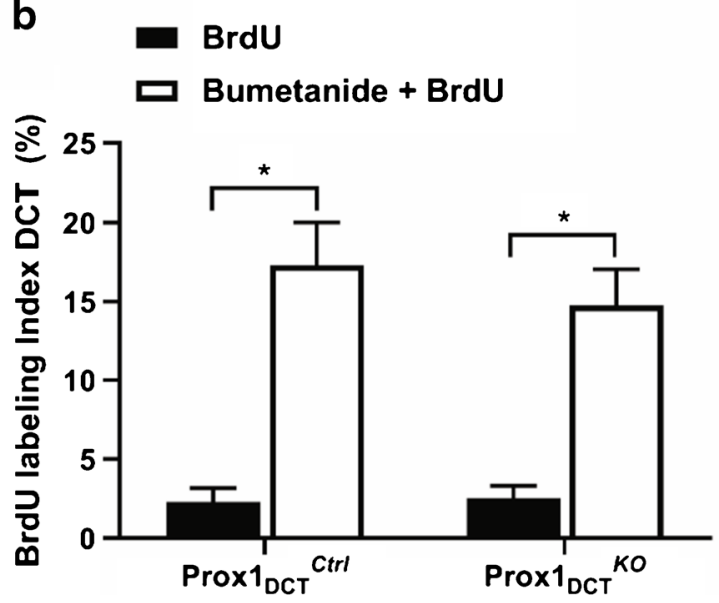

not show a gross pathological phenotype. Body weight, food, and water intake and 24-h urine excretion were comparable among the genotypes (Table 1).

\section{No effect of a Prox-1 deletion on DCT development and outgrowth}

To address the question whether Prox-1 influences the outgrowth of the DCT during renal development, Prox-1 deletion was induced in newborn mice via tamoxifen gavage of the breastfeeding mother during the first 5 days after birth. Sotreated mice were sacrificed 10 days and 6 weeks after birth and kidneys were collected for further analysis. Based on paraffin sections of kidneys immunostained with antibody against NCC, DCTs were identified and the fractional cortical tubular volume for DCTs was determined using a planimetric point-counting method (morphometry). Neither a change in kidney morphology nor in the cortical tubular DCT volume was observed in Prox- $1_{\mathrm{DCT}}{ }^{\mathrm{KO}}$ mice compared to Prox$1_{\mathrm{DCT}}{ }^{\text {Ctrl }}$ mice both 10 days and 6 weeks after birth (Fig. 3A, B). Morphologic analysis of the renal cortex (epon semi-thin sections) in both control and Prox- $1_{\mathrm{DCT}}{ }^{\mathrm{KO}}$ mice revealed no structural abnormalities of the DCT epithelium in response to a genetic loss of Prox-1 (Fig. 3C). 
a
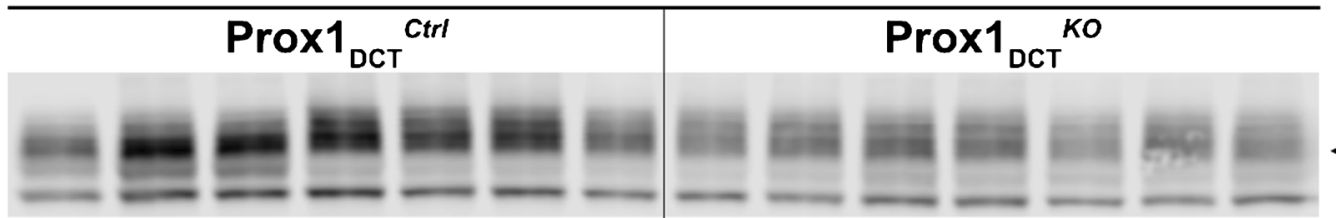

$130 \mathrm{kDa}$

pT58-NCC

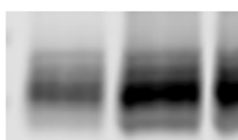

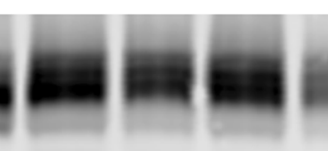

10
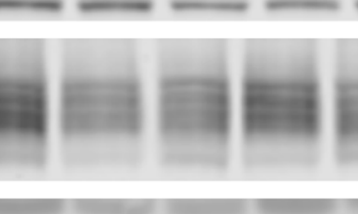

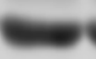

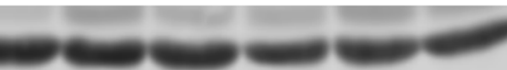

$44 \mathrm{kDa}$

b

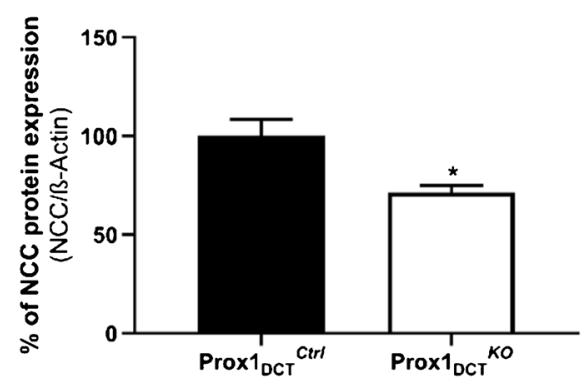

C

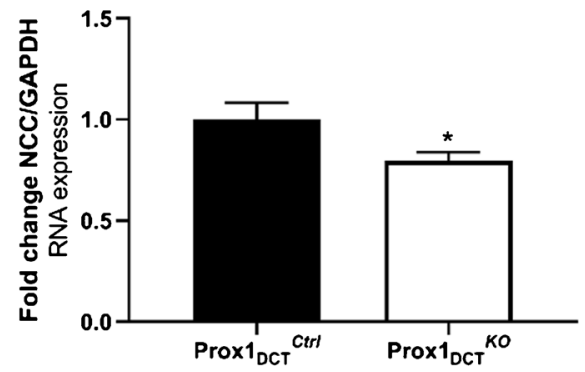

Fig. 5 NCC and phospho-NCC protein and mRNA abundance in Prox$1_{\mathrm{DCT}}{ }^{\mathrm{Ctrl}}$ versus Prox- $1_{\mathrm{DCT}}{ }^{\mathrm{KO}}$ mice. A Protein expression of total NCC and pT58-NCC in total kidney homogenates of Prox- $1_{\mathrm{DCT}}{ }^{\mathrm{Ctrl}}$ versus Prox- $1_{\mathrm{DCT}}{ }_{\mathrm{KO}}$ mice. B Densitometry analysis reveals a significant downregulation of total NCC $(p=0.0083)$ and in pT58-NCC $(p=0.0002)$ protein expression in Prox $-1_{\mathrm{DCT}}{ }^{\mathrm{KO}}$ compared to the control group. Data are

Deletion of Prox-1 does not influence DCT cell proliferation rate in response to a 3-day treatment with bumetanide

To test whether Prox-1 is involved in epithelial remodeling processes of the DCT that occur in response to a loop diuretic treatment, bumetanide was applied continuously during 3 days. The simultaneous administration of bromodeoxyuridine (BrdU) allowed for the detection of DCT cell proliferation rate. After the bumetanide treatment, a significant increase in DCT cell proliferation rate was observed in the group that received bumetanide plus BrdU compared to the group that was treated with BrdU only (Fig. 4A). However, quantitative analysis of the percentage of proliferating DCT cells under the bumetanide treatment revealed no difference mean \pm SEM, $n=7$ C Gene expression of NCC in total kidney homogenates of Prox- $1_{\mathrm{DCT}}{ }^{\mathrm{Ctrl}}$ versus Prox- $1_{\mathrm{DCT}}{ }^{\mathrm{KO}}$ mice reveals a significant downregulation of mRNA $(p=0.049)$ in Prox- $1_{\mathrm{DCT}}{ }_{\text {KO }}$ compared to the control group. Data are mean \pm SEM, $n=7$. Kidneys were studied 6 weeks after start of tamoxifen induction

in the proliferation rate between Prox- $1_{\mathrm{DCT}}{ }^{\mathrm{KO}}$ versus Prox- $1_{\text {DCT }}{ }^{\text {Ctrl }}$ mice (Fig. 4B).

\section{Overt hypomagnesemia, but no other changes in plasma electrolytes and urinary ion excretion in Prox- $1_{\mathrm{DCT}}{ }^{\mathrm{KO}}$ mice}

Analysis of plasma electrolytes revealed a significant hypomagnesemia in Prox- $1_{\mathrm{DCT}}{ }^{\mathrm{KO}}$ mice, whereas no differences in other plasma electrolyte concentrations $\left(\mathrm{Na}^{+}, \mathrm{K}^{+}, \mathrm{Ca}^{2+}\right.$, phosphate) and plasma aldosterone, 11-dehydrocorticosterone and corticosterone levels between the knockout and control groups were detected (Table 1). Urinary ion excretion $\left(\mathrm{Na}^{+}, \mathrm{K}^{+}, \mathrm{Ca}^{2+}, \mathrm{Mg}^{2+}\right)$ was similar in Prox- $1_{\mathrm{DCT}}{ }^{\mathrm{Ctrl}}$ and Prox- $1_{\mathrm{DCT}}{ }^{\mathrm{KO}}$ mice (Table 1 ). 


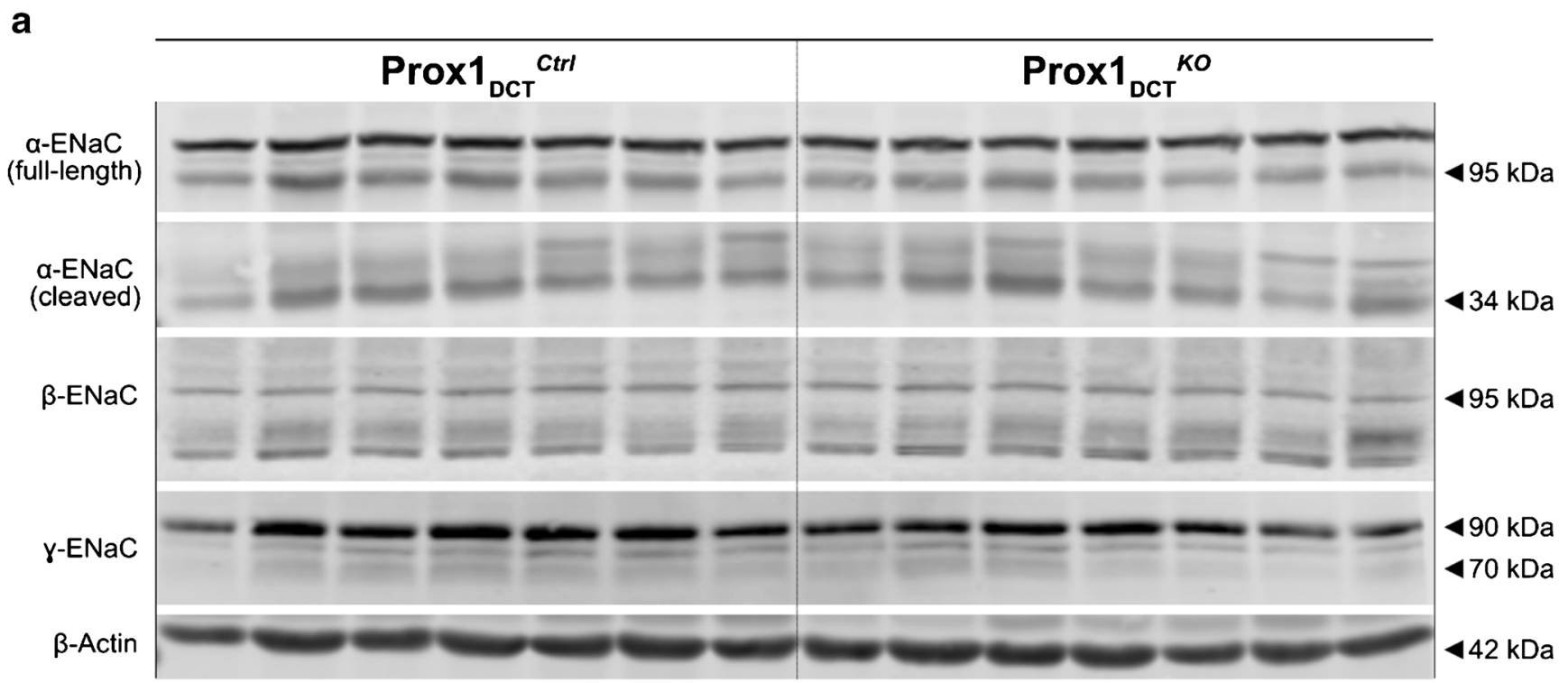

b
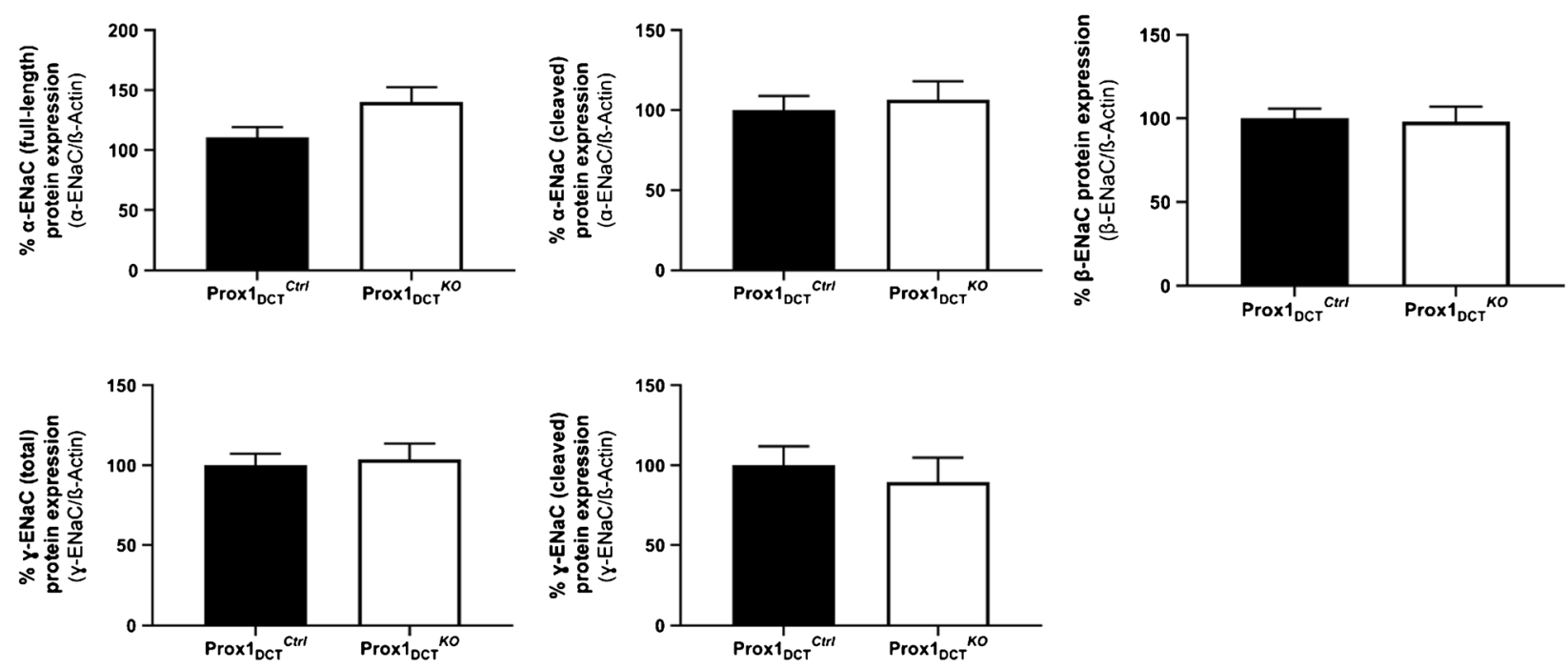

Fig. $6 \mathrm{ENaC}$ protein abundance in Prox- $1_{\mathrm{DCT}}{ }^{\mathrm{Ctrl}}$ versus Prox- $1_{\mathrm{DCT}}{ }^{\mathrm{KO}}$ mice. A Protein expression of $\alpha-, \beta-$, and $\gamma^{-E N a C}$ in total kidney homogenates of Prox $-1_{\mathrm{DCT}}{ }^{\mathrm{Ctrl}}$ versus Prox $-1_{\mathrm{DCT}}{ }^{\mathrm{KO}}$ mice. B

Densitometry analysis reveals no significant regulation of $\mathrm{ENaC}$ in Prox $-1_{\mathrm{DCT}}{ }^{\mathrm{KO}}$ compared to the control group. Data are mean $\pm \mathrm{SEM}$, $n=7$. Kidneys were studied 6 weeks after start of tamoxifen induction

\section{Decreased NCC abundance due to a loss of Prox-1 in the DCT}

Deletion of Prox-1 in the DCT in adult mice for 6 weeks resulted in a significant downregulation of total NCC and phospho-NCC protein abundance in total kidney homogenates of Prox- $1_{\mathrm{DCT}}{ }^{\mathrm{KO}}$ compared to Prox$1_{\mathrm{DCT}}{ }^{\mathrm{Ctrl}}$ (Fig. 5A, B). Similar results were shown for NCC gene expression (Fig. 5C). Interestingly, downregulation of NCC mRNA was less pronounced at 1 week after tamoxifen induction (Fig. 2), suggesting that the downregulation of NCC at the mRNA level is not an immediate effect.

\section{No change in ENaC protein expression in Prox- $1_{\mathrm{DCT}}{ }^{\mathrm{KO}}$ mice}

Protein expression analysis for $\alpha-, \beta-$, and $\mathrm{\gamma}$-ENaC revealed no significant difference in kidneys of Prox- $1_{\mathrm{DCT}}{ }^{\mathrm{Ctrl}}$ and Prox$1_{\mathrm{DCT}}^{\mathrm{KO}}$ mice for both the total/glycosylated and the cleaved forms of $\mathrm{ENaC}$ (Fig. 6A, B).

\section{Reduced protein expression of the DCT-specific $\mathbf{M g}^{2+}$ channel TRPM6 in Prox-1 ${ }_{\mathrm{DCT}}{ }^{\mathrm{KO}}$ mice}

A significant reduction in the protein expression of the DCTspecific $\mathrm{Mg}^{2+}$ channel TRPM6 was observed in total kidney 
homogenates of Prox- $1_{\mathrm{DCT}}{ }^{\mathrm{KO}}$ mice (Fig. 7A, B). In parallel, TRPM6 mRNA expression was also significantly reduced (Fig. 8A). mRNA levels of other renal magnesium transporters and proteins involved in $\mathrm{Mg}^{2+}$ homeostasis (EGF, CNNM2, EGF, FXYD2, Cldn16, Cldn19, TRPM7, Slc41a1-3) in total kidney homogenates were not altered in Prox- $1_{\mathrm{DCT}}{ }^{\mathrm{KO}}$ mice compared to their control littermates (Fig. 8B-L).

\section{Discussion}

Transcription factors are proteins that bind to particular DNA sequences in gene regulatory regions and control gene expression and activity [22]. The human genome encodes about 1600 regulatory sequence-specific transcription factors that have been identified and functionally characterized [15]. With the exception of the steroid receptors (e.g., the mineralocorticoid receptor), most studies addressing the role of transcription factors in the kidney focus on their significance during embryonic development and their regulatory function in nephrogenesis and differentiation of nephron progenitor cells [3]. Accordingly, gene mutations in transcription factors have been associated with congenital renal malformations and inherited diseases, emphasizing their important role during renal embryogenesis. For example, mutations in the transcription factor hepatocyte nuclear factor 1 homeobox B (HNF1B) gene have been shown to cause renal malformations, hypomagnesemia, and maturity-onset diabetes of the young (MODY) [1, 20]. Part of this phenotype was suggested to be related to a transcriptional downregulation of the basolateral Kir4.1/Kir5.1 $\mathrm{K}^{+}$channel in the DCT [19]. In contrary to the evolving knowledge of the role of transcription factors during renal development, only little is known about transcriptional control and regulation of gene expression in the adult kidney. Interestingly, the DCT transcriptome established previously $[7,23,33]$ revealed a high number of enriched DCT genes known to be involved in transcriptional regulation and growth control during renal development and/or tumorigenesis, suggesting that this "embryological" transcriptome contributes to the characteristic adaptation capacity and plasticity exhibited by the DCT in the adult stage.

Given its regulatory function in cell proliferation in other organs such as the retina [8], muscle tissue [18], central nervous system [16], and lymphatic tissue [49], we hypothesized that Prox-1 might play a role in DCT epithelium structural remodeling processes that occur in response to a loop diuretic treatment. However, after a 3-day treatment with bumetanide, no difference in the DCT cell proliferation rate was observed in the Prox $-1_{\mathrm{DCT}}{ }^{\mathrm{KO}}$ mice compared to the Prox $-1_{\mathrm{DCT}}{ }^{\mathrm{Crl}}$ group. A direct effect of Prox-1 on DCT cell proliferation

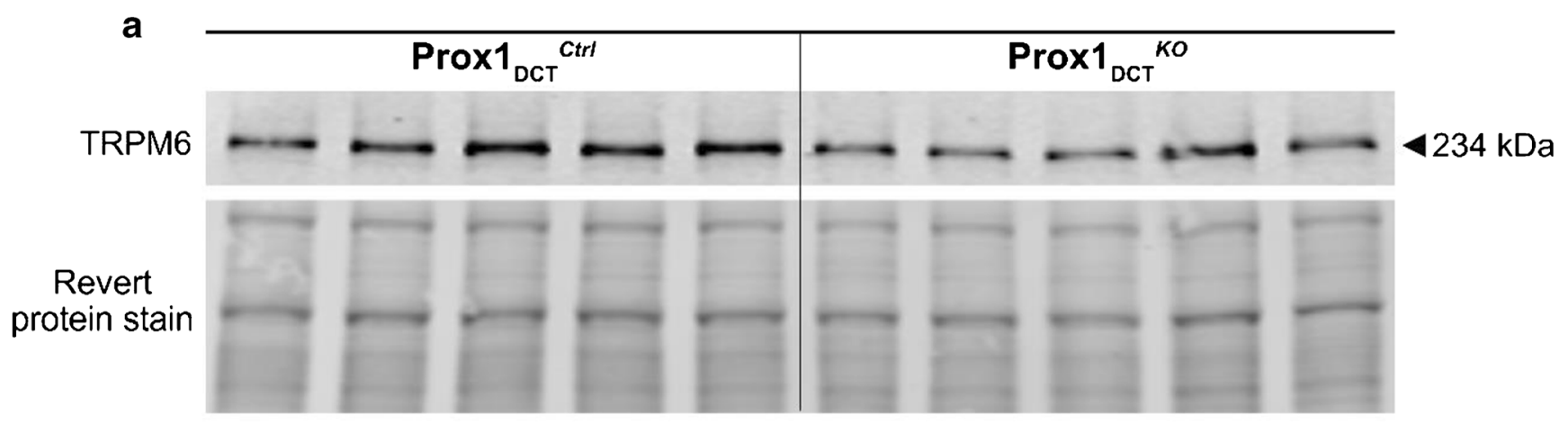

b

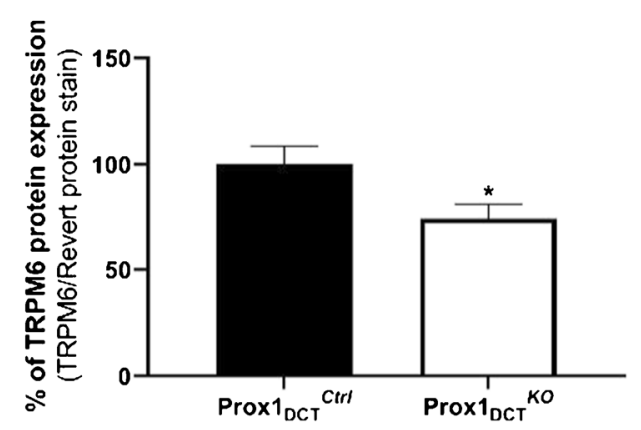

Fig. 7 TRPM6 protein and mRNA abundance in Prox- $1_{\mathrm{DCT}}{ }^{\mathrm{Ctrl}}$ versus Prox- $1_{\mathrm{DCT}}{ }_{\mathrm{KO}}$ mice. A Protein expression of TRPM6 in total kidney homogenates of Prox- $1_{\text {DCT }}{ }^{\text {trl }}$ versus Prox $-1_{\text {DCT }}{ }_{\text {KO }}$ mice. B Densitometry analysis reveals a significant down-regulation of TRPM6 $(p=0.0317)$ protein expression in Prox $-1_{\mathrm{DCT}}{ }^{\mathrm{KO}}$ compared to the control group. Data are mean $\pm \mathrm{SEM}, n=5$. Kidneys were studied six weeks after start of tamoxifen induction 

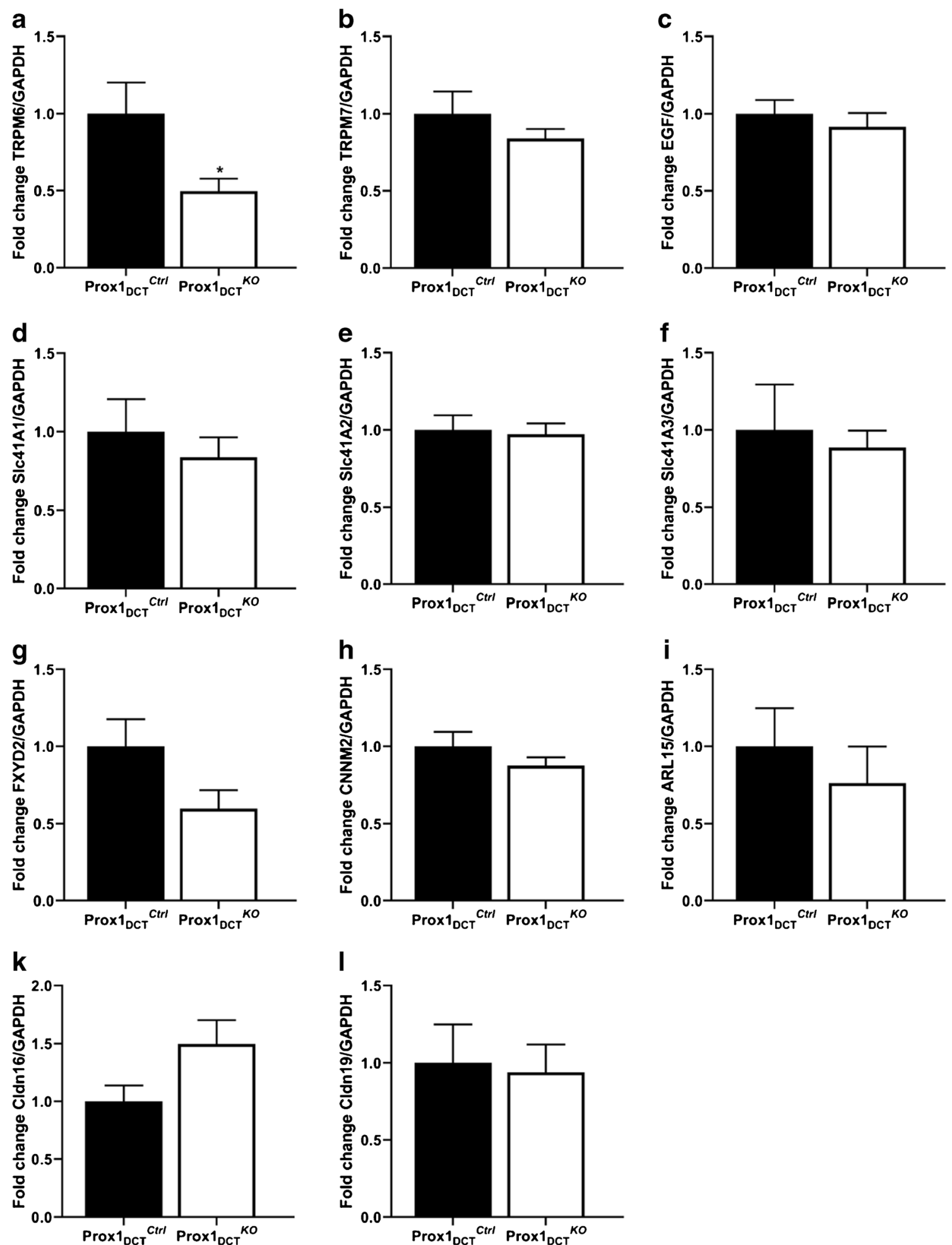

Fig. 8 mRNA expression of $\mathrm{Mg}^{2+}$ channels and regulatory proteins involved in $\mathrm{Mg}^{2+}$ homeostasis in Prox- $1_{\mathrm{DCT}}{ }^{\text {Crl }}$ versus Prox- $1_{\mathrm{DCT}}{ }^{K O}$ mice (total kidney homogenates). A TRPM6 mRNA expression is significantly downregulated in Prox $-1_{\mathrm{DCT}}{ }^{\mathrm{KO}}$ mice $(p=0.039)$. mRNA expression of B TRPM7, C EGF, D Slc41A1, E Slc41A2, F Slc41A3, G FXYD2, H CNNM2, I ARL15, K Cldn16, L Cldn19 in total kidney

homogenates is similar in Prox- $1_{\mathrm{DCT}}{ }^{\mathrm{Ctrl}}$ versus Prox $-1_{\mathrm{DCT}}{ }^{\mathrm{KO}}$ mice. Relative gene expression was analyzed with normalization against GAPDH expression (housekeeping gene). Data are mean \pm SEM, expressed as fold difference compared to the gene expression in the control group, $n=7$. Kidneys were studied 6 weeks after start of tamoxifen induction 
was therefore not verifiable. Consistently, fractional cortical DCT volume remained unchanged subsequent to a loss of Prox-1, also indicating that Prox-1 is not directly involved in structural epithelial remodeling processes of the DCT.

In the developing mouse kidney, Prox-1 was demonstrated to be highly expressed in distal renal tubules, contributing to the differentiation of the medullary part of the loop of Henle [17]. Given that a main portion of the outgrowth of the NCC-positive rodent DCT takes place in the first 10 days perinatally $[37,38]$, we investigated the effect of a Prox-1 deletion in the DCT at this early time of life. Mice in which a Prox-1 deletion was introduced during the first 10 days after birth did not reveal any morphological renal abnormality and the cortical tubular DCT volume remained intact, indicating that a loss of Prox-1 in this period of nephron development does not affect DCT outgrowth. Hence, Prox-1 may be less important for the initial formation of the DCT, but rather contributes to the regulation of DCT function and ion transport at the full-grown stage.

The expression of NCC as the major sodium reabsorption pathway of the DCT was significantly decreased due to a loss of Prox-1, confirming that Prox-1 does play a modulatory role in DCT function and ion transport regulation. As no change in the cortical tubular DCT volume was observed in Prox$1_{\mathrm{DCT}}{ }^{\mathrm{KO}}$ mice neither during renal development nor at adulthood, we assume that this NCC downregulation is not due to a loss of DCT epithelium surface, but due to a NCC downregulation on the cellular level, which occurs as a consequence of the genetic disruption of Prox-1. The underlying gene networks modified by Prox-1 and resulting in this NCC downregulation remain elusive. To date, the regulation of NCC expression and phosphorylation has been understood as a complex interplay of kinases, phosphatases and ubiquitinligases [13, 34, 41, 51]. Here, we support the concept thatin addition to the already known posttranslational regulatory mechanisms - transcription factors previously linked to developmental processes but not epithelial transport, may participate in the control of DCT function.

Although the abundance of NCC as the major sodium reabsorption pathway of the DCT is significantly reduced in Prox$1_{\mathrm{DCT}}{ }^{\mathrm{KO}}$ mice, no functional consequences in renal sodium handling, especially no salt-wasting phenotype was observed. Consistently, NCC null mutations lead only to mild perturbation of sodium and fluid volume homeostasis in mice [39] and most human patients [40]. As almost every nephron segment participates in renal sodium reabsorption, compensatory mechanisms in other tubular segments that counteract NCC downregulation in the DCT are very likely to occur, even though no change in $\mathrm{ENaC}$ protein expression was demonstrated in our study.

The DCT is also a key site for $\mathrm{Mg}^{2+}$ balance and reabsorbs $10 \%$ of filtered tubular $\mathrm{Mg}^{2+}$ in an active transcellular manner via the luminal $\mathrm{Mg}^{2+}$ channel TRPM6 $[6,28,46]$. With this, the DCT represents the predominant site of specifically regulated $\mathrm{Mg}^{2+}$ excretion and ultimately controls the amount of
$\mathrm{Mg}^{2+}$ excreted in the urine, because no $\mathrm{Mg}^{2+}$ reabsorption occurs in downstream nephron segments [45]. Altered DCT structure and function either due to a genetic loss of NCC in Gitelman syndrome or an inhibition of NCC activity by thiazide-like diuretics may relevantly influence $\mathrm{Mg}^{2+}$ homeostasis and cause renal $\mathrm{Mg}^{2+}$ wasting and hypomagnesemia in mice $[25,31]$ and human patients $[9,21,35]$. Others and we previously reported a distinct reduction of TRPM6 abundance in a NCC null mutant mouse model, most probably linked to a loss of a significant portion of the DCT epithelium [31, 38]. In the current study, no change in the tubular DCT volume in Prox $-1_{\mathrm{DCT}}{ }^{\mathrm{KO}}$ mice is observed. The reduced TRPM6 expression and hypomagnesemia can hence not be explained with a loss of TRPM6 expressing DCT epithelium. One can only speculate whether the hypomagnesemic phenotype and TRPM6 downregulation in the Prox- $1_{\mathrm{DCT}}{ }^{\mathrm{KO}}$ mouse model is due to a direct or indirect regulation of TRPM6 through Prox1 or whether this occurs secondary due to reduced NCC expression and diminished transcellular sodium transport.

Surprisingly, urinary magnesium excretion was unaltered or even slightly reduced in Prox- $1_{\mathrm{DCT}}{ }^{\mathrm{KO}}$ mice despite an overt hypomagnesemia compared to the control group. This is consistent with findings in kidney-specific TRPM6 null mice, which show hypomagnesemia despite reduced urinary $\mathrm{Mg}^{2+}$ excretion [4]. It is conceivable that the downregulation of TRPM6-dependent $\mathrm{Mg}^{2+}$ transport in DCT gets compensated by an upregulation of paracellular $\mathrm{Mg}^{2+}$ reabsorption in the TAL and PT [28].

In conclusion, we developed a new mouse model for an inducible gene targeting in the renal DCT. We used this mouse model to study the DCT-specific role of the transcription factor Prox-1. While previous studies on Prox-1 and other renal transcription factors focused mainly on their role during embryonic development, the present study shows that Prox-1 has an important role in the adult DCT by controlling TRPM6-dependent $\mathrm{Mg}^{2+}$ homeostasis. The study may set an important base for future studies addressing the functional involvement of this and possibly other DCT-enriched transcription factors in regulatory pathways governing kidney function.

Supplementary Information The online version contains supplementary material available at https://doi.org/10.1007/s00424-020-02491-1.

Acknowledgments Open access funding provided by University of Zurich. The authors would like to thank Dr. G. Oliver (Chicago) for kindly providing the Prox- $1^{\text {flox }}$ mice. The authors also thank Günther Schütz (Heidelberg) and Stefan Berger (Groningen) for providing the antibody against the Cre recombinase. Finally, we thank Nadine Naegele from the ZIRP facility of the University of Zurich for magnesium and phosphate measurements.

Funding Christina Schnoz is member of the $\mathrm{UZH} \mathrm{MD} / \mathrm{PhD}$ program. Johannes Loffing is supported by research funds from the Swiss National Centre for Competence in Research "Kidney.CH" and by a project grant from the Swiss National Science Foundation (310030 173276/1). 


\section{Compliance with ethical standards}

Conflict of interest The authors declare that they have no conflict of interest.

Open Access This article is licensed under a Creative Commons Attribution 4.0 International License, which permits use, sharing, adaptation, distribution and reproduction in any medium or format, as long as you give appropriate credit to the original author(s) and the source, provide a link to the Creative Commons licence, and indicate if changes were made. The images or other third party material in this article are included in the article's Creative Commons licence, unless indicated otherwise in a credit line to the material. If material is not included in the article's Creative Commons licence and your intended use is not permitted by statutory regulation or exceeds the permitted use, you will need to obtain permission directly from the copyright holder. To view a copy of this licence, visit http://creativecommons.org/licenses/by/4.0/.

\section{References}

1. Adalat S, Woolf AS, Johnstone KA, Wirsing A, Harries LW, Long DA, Hennekam RC, Ledermann SE, Rees L, van't Hoff W, Marks SD, Trompeter RS, Tullus K, Winyard PJ, Cansick J, Mushtaq I, Dhillon HK, Bingham C, Edghill EL, Shroff R, Stanescu H, Ryffel GU, Ellard S, Bockenhauer D (2009) HNF1B mutations associate with hypomagnesemia and renal magnesium wasting. J Am Soc Nephrol 5:1123-1131

2. Bindels RJM, Hoenderop JG, Xi Q (2009) Regulation of magnesium reabsorption in DCT. Pflugers Arch - Eur J Physiol 458(1): 89-98

3. Bouchard M (2004) Transcriptional control of kidney development. Differentiation 72:295-306

4. Chubanov V, Ferioli S, Wisnowsky A, Simmons DG, Leitzinger C, Einer C, Jonas W, Shymkiv Y, Bartsch H, Braun A, Akdogan B, Mittermeier L, Sytik L, Torben F, Jurinovic V, van der Vorst EP, Weber C, Yildirim ÖA, Sotlar K, Schürmann A, Zierler S, Zischka H, Ryazanov AG, Gudermann T (2016) Epithelial magnesium transport by TRPM6 is essential for prenatal development and adult survival. Elife 5:e20914

5. Cornelius RJ, Sharma A, Su X, McMahon AP, Ellison DH, McCormick JA (2020) A novel distal convoluted tubule-specific tamoxifen-inducible Cre-recombinase driven by the $\mathrm{NaCl}$ cotransporter gene. FASEB J 34:1-1

6. Dai LJ, Ritchie G, Kerstan D, Kang HS, Cole DE, Quamme GA (2001) Magnesium transport in the renal distal convoluted tubule. Physiol Rev 81:51-84

7. De Baaij JH, Groot Koerkamp MJ, Lavrijsen M, van Zeeland F, Meijer H, Holstege FC, Bindels RJ, Hoenderop JG (2013) Elucidation of the distal convoluted tubule transcriptome identifies new candidate genes involved in renal $\mathrm{Mg}(2+)$ handling. Am J Physiol Renal Physiol 11:F1563-F1573

8. Dyer MA, Livesey FJ, Cepko CL, Oliver G (2003) Prox1 function controls progenitor cell proliferation and horizontal cell genesis in the mammalian retina. Nat Genet 34:53-58

9. Ellison DH (2000) Divalent cation transport by the distal nephron: insights from Bartter's and Gitelman's syndromes. Am J Physiol Renal Physiol 279:F616-F625

10. Elsir T, Smits A, Lindstrom MS, Nister M (2012) Transcription factor PROX1: its role in development and cancer. Cancer Metastasis Rev 31:793-805

11. Glover M, Mercier Zuber A, Figg N, O'Shaughnessy KM (2010) The activity of the thiazide-sensitive $\mathrm{Na}(+)-\mathrm{Cl}(-)$ cotransporter is regulated by protein phosphatase PP4. Can J Physiol Pharmacol 88:986-995

12. Hadchouel J, Delaloy C, Faure S, Achard JM, Jeunemaitre X (2006) Familial hyperkalemic hypertension. J Am Soc Nephrol 17:208-217

13. Hadchouel J, Ellison DH, Gamba G (2016) Regulation of renal electrolyte transport by WNK and SPAK-OSR1 kinases. Annu Rev Physiol 78:367-389

14. Harvey NL, Srinivasan RS, Dillard ME, Johnson NC, Witte MH, Boyd K, Sleeman MW, Oliver G (2005) Lymphatic vascular defects promoted by Prox1 haploinsufficiency cause adult-onset obesity. Nat Genet 37:1072-1081

15. Ignatieva EV, Levitsky VG, Kolchanov NA (2015) Human genes encoding transcription factors and chromatin-modifying proteins have low levels of promoter polymorphism: a study of 1000 genomes project data. Int J Genomics 2015:260159-260115. https:// doi.org/10.1155/2015/260159

16. Kato K, Konno D, Berry M, Matsuzaki F, Logan A, Hidalgo A (2015) Prox 1 inhibits proliferation and is required for differentiation of the oligodendrocyte cell lineage in the mouse. PLoS One 10(12): $\mathrm{e} 0145334$

17. Kim YM, Kim WY, Nam SA, Choi AR, Kim H, Kim YK, Kim HS, Kim J (2015) Role of Prox1 in the transforming ascending thin limb of Henle's loop during mouse kidney development. PLoS One e0127429

18. Kivelä R, Salmela I, Nguyen Y, Petrova TV, Koistinen HA, Wiener Z, Alitalo K (2016) The transcription factor Prox1 is essential for satellite cell differentiation and muscle fibre-type regulation. Nat Commun 7:13124

19. Kompatscher A, de Baaij JHF, Aboudehen K, Hoefnagels APWM, Igarashi P, Bindels RJM, Veenstra GJC, Hoenderop JGJ (2017) Loss of transcriptional activation of the potassium channel Kir5.1 by HNF $1 \beta$ drives autosomal dominant tubulointerstitial kidney disease. Kidney Int 5:1145-1156

20. Konrad M, Schlingmann KP (2014) Inherited disorders of renal hypomagnesaemia. Nephrol Dial Transplant 29(suppl 4):iv63-iv71

21. Kuller L, Farrier N, Caggiula A, Borhani N, Dunkle S (1985) Relationship of diuretic therapy and serum magnesium levels among participants in the Multiple Risk Factor Intervention Trial. Am J Epidemiol 122:1045-1059

22. Lambert SA, Jolma A, Campitelli LF, Das PK, Yin Y, Albu M, Chen X, Taipale J, Hughes TR, Weirauch MT (2018) The human transcription factors. Cell 172:650-665

23. Lee JW, Chou CL, Knepper MA (2015) Deep sequencing in microdissected renal tubules identifies nephron segment-specific transcriptomes. J Am Soc Nephrol 11:2669-2677

24. Loffing J, Loffing-Cueni D, Valderrabano V, Kläusli L, Hebert SC, Rossier BC, Hoenderop JG, Bindels RJ, Kaissling B (2001) Distribution of transcellular calcium and sodium transport pathways along mouse distal nephron. Am J Physiol Renal Physiol 281(6): F1021-F1027

25. Loffing J, Vallon V, Loffing-Cueni D, Aregger F, Richter K, Pietri L, Bloch-Faure M, Hoenderop JG, Shull GE, Meneton P, Kaissling $\mathrm{B}$ (2004) Altered renal distal tubule structure and renal $\mathrm{Na}(+)$ and $\mathrm{Ca}(2+)$ handling in a mouse model for Gitelman's syndrome. J Am Soc Nephrol 15:2276-2288

26. Madisen L, Zwingman TA, Sunkin SM, Oh SW, Zariwala HA, Gu H, Ng LL, Palmiter RD, Hawrylycz MJ, Jones AR, Lein ES, Zeng $\mathrm{H}$ (2010) A robust and high-throughput Cre reporting and characterization system for the whole mouse brain. Nat Neurosci 13:133140

27. Mayan H, Farfel Z, Karlish SJD (2018) Renal Mg handling, FXYD2 and the central role of the Na,K-ATPase. Physiol Rep 6: $1-10$

28. McCormick JA, Ellison DH (2015) Distal convoluted tubule. Compr Physiol 5:45-98 
29. Meij IC, Koenderink JB, van Bokhoven H, Assink KF, Groenestege WT, de Pont JJ, Bindels RJ, Monnens LA, van den Heuvel LP, Knoers NV (2000) Dominant isolated renal magnesium loss is caused by misrouting of the $\mathrm{Na}(+), \mathrm{K}(+)$-ATPase gamma-subunit. Nat Genet 26:265-266

30. Moes AD, van der Lubbe N, Zietse R, Loffing J, Hoorn EJ (2014) The sodium chloride cotransporter SLC12A3: new roles in sodium, potassium, and blood pressure regulation. Pflugers Arch - Eur J Physiol 466:107-118

31. Nijenhuis T, Vallon V, van der Kemp AW, Loffing J, Hoenderop JG, Bindels RJ (2005) Enhanced passive Ca2+ reabsorption and reduced $\mathrm{Mg} 2+$ channel abundance explains thiazide-induced hypocalciuria and hypomagnesemia. J Clin Invest 115:1651-1658

32. Oliver G, Sosa-Pineda B, Geisendorf S, Spana EP, Doe CQ, Gruss P (1993) Prox1, a prospero-related homeobox gene expressed during mouse development. Mech Dev 44(1):3-16

33. Picard N, Trompf K, Yang CL, Miller RL, Carrel M, Loffing-Cueni D, Fenton RA, Ellison DH, Loffing J (2014) Protein phosphatase 1 inhibitor-1 deficiency reduces phosphorylation of renal $\mathrm{NaCl}$ cotransporter and causes arterial hypotension. J Am Soc Nephrol 25:511-522

34. Ronzaud C, Loffing-Cueni D, Hausel P, Debonneville A, Malsure SR, Fowler-Jaeger N, Boase NA, Perrier R, Maillard M, Yang B, Stokes JB, Koesters R, Kumar S, Hummler E, Loffing J, Staub O (2013) Renal tubular NEDD4-2 deficiency causes NCC-mediated salt-dependent hypertension. J Clin Invest 123:657-665

35. Ryan MP, Devane J, Ryan MF, Counihan TB (1984) Effects of diuretics on the renal handling of magnesium. Drugs 28(suppl1): $167-181$

36. Schlingmann K, Weber S, Peters M, Niemann Nejsum L, Vitzthum H, Klingel K, Kratz M, Haddad E, Ristoff E, Dinour D, Syrrou M, Nielsen S, Sassen M, Waldegger S, Seyberth W, Konrad M (2002) Hypomagnesemia with secondary hypocalcemia is caused by mutations in TRPM6, a new member of the TRPM gene family. Nat Genet 31:166-170

37. Schmitt R, Ellison DH, Farman N, Rossier BC, Reilly RF, Reeves WB, Oberbäumer I, Tapp R, Bachmann S (1999) Developmental expression of sodium entry pathways in rat nephron. Am J Physiol Renal Physiol 276(3):F367-F381

38. Schnoz C, Carrel M, Loffing J (2020) Loss of NCC impairs the outgrowth of the renal distal convoluted tubule, Nephrol Dial Transpl gfz172, https://doi.org/10.1093/ndt/gfz172

39. Schultheis PJ, Lorenz JN, Meneton P, Niema ML, Riddle TM, Flagella M, Duffy JJ, Doetschman T, Miller ML, Sholl GE (1998) Phenotype resembling Gitelman's syndrome in mice lacking the apical Na+-Cl- cotransporter of the distal convoluted tubule. J Biol Chem 273:1-6

40. Simon DB, Nelson-Williams C, Johnson Bia M, Ellison D, Karet FE, Molina AM, Vaara I, Iwata F, Cushner HM, Koolen M, Gainza
FJ, Gitelman HJ, Lifton RP (1996) Gitelman's variant of Bartter's syndrome, inherited hypokalaemic alkalosis, is caused by mutation sin the thiazide-sensitive $\mathrm{NaCl}$ cotransporter. Nat Genet 12:24-30

41. Sohara E, Uchida S (2015) Kelch-like 3/Cullin 3 ubiquitin ligase complex and WNK signaling in salt-sensitive hypertension and electrolyte disorder. Nephrol Dial Transplant 9:1417-1424

42. Strajhar P, Schmid Y, Liakoni E, Dolder PC, Rentsch KM, Kratschmar DV, Odermatt A, Liechti ME (2016) Acute effects of lysergic acid diethylamide on circulating steroid levels in healthy subjects. J Neuroendocrinol 28(3):12374. https://doi.org/10.1111/ jne. 12374

43. Thebault S, Alexander RT, Tiel Groenestege WM, Hoenderop JG, Bindels RJ (2009) EGF increases TRPM6 activity and surface expression. J Am Soc Nephrol 20:78-85

44. Trepiccione F, Soukaseum C, Iervolino A, Petrillo F, Zacchia M, Schutz G, Eladari D, Capasso G, Hadchouel J (2016) A fatemapping approach reveals the composite origin of the connecting tubule and alerts on "single-cell"-specific KO model of the distal nephron. Am J Physiol Renal Physiol 311(5):F901-F906

45. Van der Wijst J, Belge H, Bindels RJM, Devuyst O (2019) Learning physiology from inherited kidney disorders. Physiol Rev 99(3):1575-1653

46. Voets T, Nilius B, Hoefs S, van der Kemp AW, Droogmans G, Bindels RJ, Hoenderop JG (2004) TRPM6 forms the Mg2+ influx channel involved in intestinal and renal $\mathrm{Mg} 2+$ absorption. J Biol Chem 279:19-25

47. Wagner CA, Lükewille U, Valles P, Breton S, Brown D, Giebisch GH, Geibel JP (2003) A rapid enzymatic method for the isolation of defined kidney tubule fragments from mouse. Pflugers Arch - Eur J Physiol 446:623-632

48. Walder R, Landau D, Meyer P, Shalev H, Tsolia M, Borochowitz Z, Boettger MB, Beck GE, Engelhardt RK, Carmi R, Sheffield VC (2002) Mutation of TRPM6 causes familial hypomagnesemia with secondary hypocalcemia. Nat Genet 31:171-174

49. Wigle JT, Oliver G (1999) Prox1 function is required for the development of the murine lymphatic system. Cell 98(6):769-778

50. Wigle JT, Chowdhury K, Gruss P, Oliver G (1999) Prox 1 function is crucial for mouse lens-fibre elongation. Nat Genet 21:318-322

51. Wilson FH, Disse-Nicodeme S, Choate KA, Ishikawa K, NelsonWilliams C, Desitter I, Gunel M, Milford DV, Lipkin GW, Achard JM, Feely MP, Dussol B, Berland Y, Unwin RJ, Mayan H, Simon DB, Farfel Z, Jeunemaitre X, Lifton RP (2001) Human hypertension caused by mutations in WNK kinases. Science 293:1107-1112

Publisher's note Springer Nature remains neutral with regard to jurisdictional claims in published maps and institutional affiliations. 